\title{
Konflik sosial dalam novel $A i b$ dan Nasib karya Minanto berdasarkan perspektif George Simmel
}

\section{Devi Laila Maghfiroh ${ }^{\mathrm{I}^{*}}$, Moh. Zawawi ${ }^{2}$}

Universitas Islam Negeri Maulana Malik Ibrahim Malang, Jl. Gajayana No. 50, Malang, Indonesia

I7310191@student.uin-malang.ac.id; zawawi@bsa.uin-malang.ac.id

*Corresponding author:17310191@student.uin-malang.ac.id

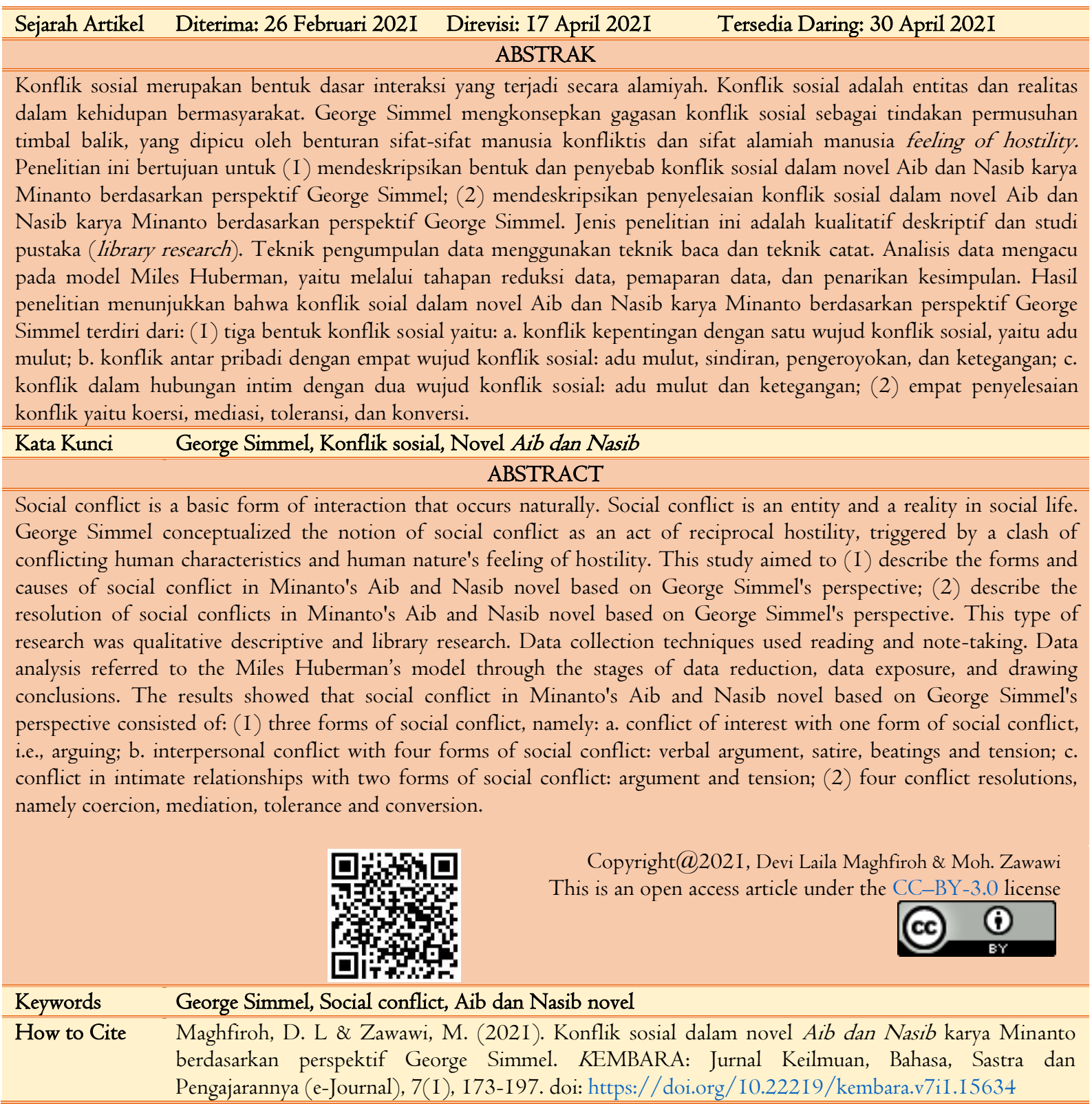

\section{PENDAHULUAN}

Konflik sosial hingga saat ini masih menjadi kekhawatiran bersama yang tidak pernah mencapai garis akhir. Konflik sosial cenderung mengalami peningkatan secara kuantitas maupun kualitas seiring permasalahan sosial yang semakin kompleks. Konflik-konflik di masyarakat secara umum diakibatkan oleh ketidakadilan, bentrok pemahaman, dan kesenjangan ekonomi. Tidak dapat dipungkiri bahwa 
beberapa konflik sosial membawa fungsi positif untuk keteraturan masyarakat. Akan tetapi, seberapa besar dampak positif yang ditimbulkan maka akan tetap membawa dampak negatif seperti kerugian harta benda bahkan nyawa dalam perealisasian suatu tujuan (Setiawan dan Musaffak, 2019). Konflik sosial memang tidak dapat dilepaskan dari kehidupan sosial bahkan hampir seluruhnya mengarah pada tindak kekerasan dan berpotensi merugikan banyak pihak. Oleh karena itu, studi konflik sosial sangat penting dilakukan guna mendapatkan pengetahuan akan solusi terbaik, sehingga dapat meminimalisir dampak negatif yang ditimbulkan melalui penyelesaian konflik secara komprehensif dan holistik dengan penuh kearifan dan kebijaksanaan (Sumarno, 20I4).

Konflik dalam Kamus Besar Bahasa Indonesia berarti pertentangan atau percekcokan, baik pertentangan ide maupun fisik oleh pihak-pihak yang berseberangan. Menurut Simmel konflik merupakan problematika umum, berulang-ulang, dan tidak pernah dapat diselesaikan sepenuhnya. Konflik merupakan fenomena yang menjadi bagian hidup manusia sosialis dan politis (Beeghley, I998). Secara kodrati, manusia adalah makhluk konfliktis yang selalu terikat pada perbedaan, persaingan, pertentangan baik terpaksa maupun sukarela. Konflik berakar dari perbedaan atau benturan kepentingan, keinginan, pendapat, dan tujuan sehingga terjadi persinggungan. Sebagaimana (Jamil 2015) menjelaskan bahwa konflik adalah persepsi mengenai perbedaan kepentingan atau kepercayaan bahwa ambisi maupun keinginan pihak yang berkonflik tidak dicapai secara simultan (Setiawan dan Musaffak, 2020). Oleh karena itu, konflik adalah entitas dan kebutuhan yang tidak dapat dilepaskan dari kehidupan sosial (Setiadi, 2020).

Konflik sosial berarti konflik yang terjadi dalam kehidupan sosial. Konflik menjadi unsur terpenting sebagai mekanisme yang mendorong dinamika dan perubahan sosial politik (Farida dan Andalas, 2019). Konflik sosial merupakan bagian dari interaksi sosial yang bersifat diasosiatif yang berperan penting dalam proses pembentukan dan perubahan masyarakat. Istilah konflik sosial selalu dikonotasikan negatif yang mengarah pada ketidakstabilan, ketidakamanan, dan ketidakharmonisan dalam masyarakat. Akan tetapi, hakikatnya konflik sosial memiliki fungsi positif sebagaimana dikatakan George Simmel (1918) dan Lewis Coser (1957), konflik sosial merupakan faktor positif yang mengarah pada penyatuan masyarakat. Konflik sosial adalah prinsip operasional yang menjaga keseluruhan dan keseimbangan sosial (Susan, 2019). Konsep umum konflik sosial mencakup fenomena mulai dari peristiwa non-kekerasan, tetapi konfliktual hingga tindak kekerasan berskala kecil (De Juan et al., 2020). Adapun esensi tujuan konflik sosial adalah menghasilkan keragaman (Thomas \& Frisby, 1985).

Kajian konflik sosial masih menjadi topik bahasan yang memiliki urgensi dan sangat menarik untuk dikupas tuntas hingga saat ini, karena dapat memberikan perspektif analisis yang komprehensif seputar dimensi konflik untuk mengetahui skala, latar belakang, perkembangan, dan solusi terbaik menangani konflik di masyarakat. Perkembangan kajian konflik sosial berjalan seiring dengan kompleksitas masyarakat dalam berinteraksi sosial secara kontinu dalam ruang dan waktu yang dinamis. Tujuan mempelajari konflik sosial adalah memahami aspek yang mendasari masyarakat dan memahami segala resiko permasalahan sosial. Konflik sosial dapat muncul dari dinamika sosio-psikologis seperti nilai-nilai yang berlawanan, dalam keinginan atau kebutuhan sebagai perjuangan atas kekuasaan dan kontrol sumber daya (Fernandez, 202I). Oleh karena itu, konflik sosial menjadi wajah yang mencerminkan realitas masyarakat berupa proses perbenturan sosial baik yang bersifat konstruktif maupun destruktif. Sebagaimana Simmel menyebutnya sebagai konflik fungsional dan disfungsional (Grossmann, 2019).

Dalam memetakan fenomena sosial dan segala hal ihwal yang melekat pada masyarakat, media karya sastra khususnya novel dianggap mampu merefleksikan keadaan sosial masyarakat (Ardias et al., 2019; Purba, 2010). Sebagaimana Alan Swingewood menjelaskan bahwa karya sastra adalah hasil dialektika pemikiran yang merefleksikan realitas masyarakat (Pincott, 1970). Objek kajian penelitian ini adalah novel berjudul $A i b$ dan Nasib karya Minanto. Novel yang berhasil memenangkan sayembara novel Dewan Kesenian Jakarta pada tahun 2019 ini menyajikan refleksi kompleksitas beragam konflik 
masyarakat yang bersumber dari permasalahan-permasalahan sosial, seperti kemiskinan, kebodohan, politik electoral, kisah asmara, hingga pengaruh teknologi. Oleh karena itu, novel ini sangatlah sesuai dikupas menggunakan metode pendekatan sosiologi sastra khususnya konflik sosial.

Novel Aib dan Nasib karya Minanto menyajikan kerumitan kehidupan warga Desa Tegalurung dalam bentuk fragmen episodik dengan alur yang sangat kompleks, terstruktur, dan gairah eksperimentasi menambah keindahan khazanah narasi. Novel dengan 263 halaman ini menggambarkan dekonstruksi atas ruang hidup berkenaan dengan kriminalitas yang tidak mengenal dikotomi kota dan desa. Novel ini menciptakan persepsi dan stereotip bahwa kehidupan desa tidak selalu mendamaikan, tetapi juga tidak lepas dari aib dan nasib yang rumit dan kompleks. Peneliti berkeinginan menganalisis konflik sosial dalam novel tersebut menggunakan teori sosiologi sastra, yaitu konflik sosial berdasarkan perspektif George Simmel. Konsep George Simmel dalam mendefinisikan konflik adalah sebagai konsep tindakan permusuhan timbal balik. Simmel berpendapat bahwa setiap individu memiliki insting saling bermusuhan yang disebabkan oleh feeling of hostility secara alamiah (Simmel \& Wolff, I978).

George Simmel adalah penggagas pertama kali istilah sosiologi konflik dalam American Journal of Sociology tahun I903 dalam artikelnya yang berjudul The Sociology of Conflict: I Bryan S. Turner melalui classifical sociology. Oleh karenanya, George Simmel mendapat julukan sebagai bapak sosiologi konflik. Simmel menganggap bahwa konflik adalah drama kehidupan sosial yang harus dihargai. Menurutnya kehidupan sosial merupakan medan pertempuran yang terus diperebutkan (Kaern et al., 1990). Sosiologi konflik berakar dari masyarakat yang mengalami pergeseran nilai dan struktural serta dinamika kekuasaan. Menurut Simmel, konflik merupakan bagian dari interaksi sosial yang menciptakan batasan-batasan dengan memperkuat kesadaran internal sehingga terbedakan atau terpisahkannya antarkelompok. Simmel mengatakan bahwa penyebab konflik adalah kebencian, kecemburuan, keinginan, dan nafsu. Adapun tindakan timbal balik dalam konflik dipicu oleh kepentingan praktis, keyakinan religious, insting erotis, kesenangan bermain-main, pekerjaan, dan keharusan bertahan hidup. Simmel menegaskan bahwa permusuhan timbal balik akan mengakibatkan berdirinya identitas dari berbagai kelompok, tetapi juga memelihara keseluruhan sistem sosial (Sipayung, 2016). Oleh karena itu, konflik sosial merupakan manifestasi dari munculnya kelompok dengan beragam kepentingannya (Cuppen, 2018).

Tiga kunci utama perspektif sosiologi sastra George Simmel adalah relasionisme, sosiasi, dan bentuk-bentuk sosial. Relasionisme berarti unsur-unsur sosial harus saling berkaitan secara totalitas. Bentuk-bentuk sosial mengarah pada keberadaan lembaga sosial, seperti keluarga, jaringan, bentuk pertukaran sosial, dan lain-lain. Adapun sosiasi merupakan proses yang menyatukan bagian-bagian menjadi keseluruhan sistem. Simmel menjelaskan hubungan konflik dan mediasi yang menarik, yaitu konsep $d y a d$ dan triad. Hubungan dyad yaitu hubungan yang terdiri dari dua peserta yang bersifat konfrontatif. Adapun hubungan triad memungkinkan adanya mediator yang mengarahkan alur konflik tersebut, yaitu berposisi sebagai penengah dan mencapai kesepakatan ataupun menciptakan konflik terus-menerus demi kepentingannya sendiri (Susan, 2019).

Simmel juga memperhatikan hubungan sosial dalam konteks sistematik. Dalam hubungan superordinat dan subordinat sangat dimungkinkan terjadinya konflik bahkan dalam hubungan yang sangat erat sekalipun sering terjadi ketegangan dan percekcokan. Konflik sosial menurut Simmel terdiri atas konflik pertandingan antagonistik, konflik hukum, konflik mengenai prinsip-prinsip dasar (kepentingan), konflik antar pribadi, konflik dalam hubungan yang intim, dan konflik untuk menghancurkan kelompok (Johnson, 2008). Keberhasilan resolusi konflik dilihat dari beberapa aspek, yaitu hilangnya dasar konflik, hilangnya kekuasaan dari salah satu pihak, objek pertikaian dapat dibagi, memberikan hadiah bagi yang kalah, dan pihak ketiga bersifat netral dan menjadi penengah. Konflik yang terselesaikan dengan arif dan bijaksana akan bersifat positif konstruktif bagi perubahan sosial masyarakat (Susan, 2019). Penyelesaian konflik sosial adalah tanggung jawab setiap elemen masyarakat melalui beragam metodologi dan dialog bersama (Vargas-Lama \& Osorio-Vera, 2020). 
Setelah pemaparan di atas, penelitian dengan metode pendekatan konflik sosial bukanlah kajian yang pertama kali. Peneliti memperoleh beberapa kajian terdahulu diantaranya adalah: (I) konflik antara kelompok abangan dan santri dalam novel Kantring Genjer-Genjer karya Teguh Winarsho AS: Kajian soisologi sastra (Sugiono dan Mulyono, 2020); (2) konflik sosial pada novel Lelaki Harimau karya Eka Kurniawan (Nugraha et al., 2019); (3) konflik Sosial dalam Novel Seperti Dendam, Rindu Harus Dibayar Tuntas karya Eka Kurniawan (Maiti \& Bidinger, I98I).

Berdasarkan paparan kajian terdahulu di atas, peneliti menemukan perbedaan dan persamaan dengan penelitian yang sekarang. Adapun fungsi kajian terdahulu adalah menentukan posisi peneliti guna memastikan orisinalitas penelitian. Pada kajian terdahulu yang pertama, persamaan dengan penelitian sekarang adalah terletak pada pisau analisis yang digunakan yaitu konflik sosial perspektif George Simmel. Adapun perbedaannya terletak pada fokus dan objek penelitian. Penelitian terdahulu bertujuan untuk menganalisis bentuk dan penyebab konflik pada kelompok abangan dan santri dalam novel Kantring Genjer-Genjer karya Teguh Winarsho AS, sedangkan penelitian sekarang bertujuan untuk menganalisis bentuk, penyebab sekaligus solusi penyelesaian konflik sosial khususnya pada masyarakat Indramayu dalam novel Aib dan Nasib.

Pada kajian terdahulu yang kedua, persamaan dengan penelitian sekarang adalah terletak pada topik pembahasan, yaitu konflik sosial. Adapun perbedaannya terletak pada pendekatan, fokus, dan objek penelitian. Penelitian terdahulu menggunakan pendekatan sosiologi sastra secara umum dengan fokus analisis bentuk dan faktor penyebab masalah sosial dalam novel Lelaki Harimau. Adapun penelitian sekarang menggunakan pendekatan khusus konflik sosial perspektif George Simmel dengan fokus analisis bentuk, penyebab, dan solusi pada masalah sosial khusus pada konflik sosial dalam novel Aib dan Nasib.

Pada kajian terdahulu yang ketiga, persamaan dengan penelitian sekarang adalah terletak pada fokus penelitian, yaitu bentuk, penyebab, dan solusi konflik sosial dalam novel. Adapun perbedaan dengan penelitian sekarang adalah terletak pada pendekatan dan objek penelitian. Penelitian terdahulu menggunakan metode pendekatan sosiologi sastra secara umum pada novel Seperti Dendam, Rindu Harus Dibayar Tuntas. Penelitian sekarang menggunakan pisau analisis khusus konflik sosial khusus George Simmel. Dalam penelitian sekarang, peneliti menemukan data konflik sosial dalam novel sebagai replika dari realitas masalah sosial masyarakat. Hasil temuan peneliti terfokus pada konflik sosial yang terjadi dalam novel sekaligus data faktual masyarakat Indramayu. Keunggulan dalam penelitian sekarang adalah mengaji realitas konflik sosial masyarakat Indramayu melalui karya sastra sekaligus menghubungkan dengan fakta lapangan realitas sosial masyarakat Indramayu yang melatarbelakangi konflik dalam kehidupan nyata masyarakat. Oleh karena itu, penelitian ini mampu menerapkan sastra sebagai refleksi masyarakat.

Permasalahan yang akan dipecahkan dalam penelitian ini yaitu "Konflik Sosial dalam novel Aib dan Nasib karya Minanto berdasarkan perspektif George Simmel”. Berdasarkan fokus penelitian, maka tujuan penelitian secara spesifik adalah: (I) mendeskripsikan bentuk dan penyebab konflik sosial dalam novel Aib dan Nasib karya Minanto berdasarkan perspektif George Simmel; serta (2) mendeskripsikan penyelesaian konflik sosial dalam novel Aib dan Nasib karya Minanto berdasarkan perspektif George Simmel.

\section{METODE}

Penelitian ini merupakan penelitian kualitatif deskriptif dan library research. Penelitian kualitatif adalah penelitian yang bersifat deskriptif analitik dengan memahami, mendeskripsikan, dan analisis fenomena sosial, proses, dan makna suatu konteks atau lingkungan sosial. Penelitian kualitatif menempatkan peneliti sebagai instrumen utama yang berfokus pada deskripsi dan analisis, mencari kompleksitas dan kontekstualisasi, serta mengutamakan pemahaman dan proses induktif (Ravitch \& Carl, 2019). Penelitian deskriptif bertujuan memberikan gambaran fenomena alamiah dan menjawab fokus penelitian dan hipotesis yang bersifat univariate, normative, ataupun korelatif. Pemaparan hasil 
analisis secara deskriptif bersamaan dengan interpretasi peneliti merupakan tahapan dalam penelitian kualitatif (Bickman \& Rog, 2009). Penelitian kualitatif deskriptif ini bertujuan untuk menganalisis, mendeskripsikan, dan memberikan interpretasi peneliti terhadap fenomena sosial berupa konflik sosial yang direfleksikan dalam novel Aib dan Nasib karya Minanto. Penelitian ini mengacu pada teori konflik sosial berdasarkan perspektif George Simmel sebagai pisau analisis dalam mengupas data dalam objek penelitian. Sumber data primer penelitian ini adalah novel berjudul Aib dan Nasib karya Minanto, khususnya kalimat-kalimat yang mengandung konflik sosial. Novel Aib dan Nasib terbit pada Juli 2020 dengan 263 halaman. Novel yang berhasil memenangkan Sayembara Novel Dewan Kesenian Jakarta tahun 2019 ini menceritakan kehidupan warga Desa Tegalurung, Indramayu. Adapun data sekunder dalam penelitian ini berupa review novel Aib dan Nasib, berita-berita Tegalurung, Indramayu, bukubuku pendukung, artikel, jurnal, serta berbagai literatur yang berkaitan dengan konflik sosial George Simmel. Teknik pengumpulan data melalui teknik baca intensif kritis dan teknik catat dalam mengidentifikasi konflik sosial yang direfleksikan dalam novel. Teknik validitas data atau cross check dan recheck keseluruhan penelitian yaitu melalui tahapan peningkatan ketekunan, triangulasi, dan diskusi teman sejawat. Adapun analisis penelitian mengacu pada model Miles dan Huberman yang terdiri atas reduksi data, pemaparan data, dan penarikan kesimpulan (Miles et al, 2014). Dalam tahapan reduksi data, peneliti hanya memfokuskan perhatian pada data yang dibutuhkan yaitu bentuk, faktor penyebab, dan penyelesaian konflik sosial untuk mengerucutkan pembahasan dan merelevansikan sesuai fokus penelitian. Peneliti melakukan seleksi data terbatas pada dialog yang menggambarkan fenomena konflik sosial dan pelataran yang menjelaskan faktor penyebab maupun penyelesaian konflik sosial. Pada tahapan pemaparan data, peneliti memaparkan data secara rinci dan runtut dalam bentuk tabel dan uraian hasil analisis dan interpretasi peneliti. Pada proses penarikan kesimpulan, peneliti mengambil garis besar hasil pembahasan penelitian berupa kesimpulan substantif dan formatif.

\section{HASIL DAN PEMBAHASAN}

Berdasarkan eksplorasi peneliti dalam novel Aib dan Nasib, maka pada tahapan ini peneliti akan memaparkan hasil perolehan, validasi, dan analisis data dalam bentuk tabel dan uraian deskriptif dari hasil analisis dan interpretasi peneliti. Data perolehan peneliti berupa kalimat-kalimat dialog yang merepresentasikan konflik sosial. Berdasarkan fokus penelitian, peneliti membagi dua sub bab pembahasan, yaitu: (I) bentuk dan penyebab konflik sosial dalam novel Aib dan Nasib karya Minanto berdasarkan perspektif George Simmel; (2) penyelesaian konflik sosial dalam novel Aib dan Nasib karya Minanto berdasarkan perspektif George Simmel. Pemaparannya lengkapnya sebagaimana Tabel I. 
Tabel I. Konflik sosial dalam novel Aib dan Nasib

\begin{tabular}{|c|c|c|c|}
\hline Bentuk konflik & Wujud konflik & Pihak yang berkonflik & Penyelesaianan konflik \\
\hline \multirow{2}{*}{ Konflik kepentingan } & \multirow{2}{*}{ Adu mulut } & Marlina dengan Nurumubin & Toleransi \\
\hline & & Gulabia dengan Kartono & Koersi \\
\hline \multirow{7}{*}{ Konflik antar pribadi } & \multirow{3}{*}{ Adu mulut } & Bagong dengan Boled Boleng & Koersi \\
\hline & & Ratminah dan Rusniti & Mediasi \\
\hline & & Marlina dengan Kaji Basuki & Koersi \\
\hline & Pengeroyokan & Boled Boleng dengan Bagong dan Susanto & Koersi \\
\hline & Sindiran & Inem dan Bagong & Toleransi \\
\hline & \multirow{2}{*}{ Ketegangan } & Mang Sota dengan Kaji Basuki & Toleransi \\
\hline & & Mang Sota dengan Boled Boleng & Toleransi \\
\hline \multirow{8}{*}{$\begin{array}{l}\text { Konflik dalam hubungan } \\
\text { intim }\end{array}$} & \multirow{4}{*}{ Adu mulut } & Kicong dengan Gulabia & Toleransi \\
\hline & & Marlina dengan Eni & Jalan buntu \\
\hline & & Baridin dengan Boled Boleng & Mediasi \\
\hline & & Badrudin dengan Bagong & Jalan buntu \\
\hline & \multirow{4}{*}{ Ketegangan } & Gulabia dengan Kartono & Koersi \\
\hline & & Eni dengan Nurumubin & Mediasi \\
\hline & & Eni dengan Marlina & Konversi \\
\hline & & Bagong dengan Badrudin & Koersi \\
\hline
\end{tabular}

\section{Bentuk Konflik Sosial dalam Novel Aib dan Nasib Karya Minanto Berdasarkan Perspektif George Simmel}

Berdasarkan Tabel I, bentuk konflik sosial hasil perolehan peneliti dalam novel Aib dan Nasib karya Minanto berdasarkan perspektif George Simmel terdiri atas empat bentuk konflik, yaitu: (I) konflik kepentingan dengan wujud konflik yaitu adu mulut; (2) konflik antar pribadi dengan empat wujud konflik, yaitu adu mulut, pengeroyokan, sindiran, dan ketegangan; (3) konflik dalam hubungan intim dengan dua wujud konflik yaitu adu mulut dan ketegangan. Uraian keempat konflik sosial sebagaimana berikut penjelasannya:

\section{Konflik Kepentingan}

Konflik kepentingan merupakan konflik berupa pertentangan kepentingan ataupun keinginan. Adanya konflik kepentingan adalah akibat ketidakselarasan kepentingan antar pihak, sehingga menjadi penghambat terealisasikan kepentingan yang lain. Konflik kepentingan yang diperoleh peneliti dalam novel terdiri atas satu wujud konflik, yaitu adu mulut. Berikut penjelasannya:

Pertama, wujud konflik sosial berupa adu mulut antara tokoh Gulabia dan Kartono terdapat dalam kutipan berikut.

"Menjiijikkan! Itu jabang bayi si Kicong. Buanglah! Kau pikir aku mau memelihara darah kotor itu" / "Gara-gara kau aku jadi begini”/"Kau bilang apa tadi?" /"Kalau kau tidak meremas-remas perutku, aku tidak akan keguguran"/"Demi Gusti Pengeran bilang padaku kau tidak peduli dengan anakmu?. Katakan sekarang!”/"Kau gila Kang”/“Karena kamu aku gila. Karena kamu aku merasa lebih gila daripada siapa pun". Katakan sekarang juga!"/Gulabia pun menurut, ia kemudian menangis (Aib dan Nasib, 2019, h. I38).

Konflik sosial antara Kartono dan Gulabia yang terikat hubungan suami istri berawal dari keluhan sekaligus protes Gulabia kepada Kartono atas gugurnya bayi yang dikandung Gulabia. Adu mulut terjadi karena Kartono membantah dengan keras protes yang ditujukan kepadanya. Konflik sosial diantara keduanya terjadi akibat adanya benturan keinginan juga kebencian. Gulabia sebagaimana layaknya hati seorang ibu tentu berkeinginan melahirkan anak yang dikandungnya, tetapi berseberangan dengan Kartono yang sedikitpun tidak menginginkan kelahiran bayi yang bukan darah dagingnya. Bayi yang dikandung Gulabia tak lain merupakan darah daging Kicong, mantan kekasih Gulabia. Hal inilah yang 
mendorong Kartono melakukan kekerasan kepada Gulabia untuk membunuh anak yang dianggapnya sebagai pembawa sial dalam hidupnya itu.

Sebagaimana (Jamil 2015)menjelaskan bahwa konflik sosial tercipta karena kebencian dan benturan keinginan (Susan, 2019). Gulabia yang pada mulanya masih duduk di bangku SMA terpaksa menikah dengan Kartono akibat hamil di luar nikah bersama kekasihnya, Kicong. Gulabia menginginkan untuk mempertahankan bayi yang masih di dalam kandungannya, adapun Kartono tentu tidak menginginkan kelahiran bayi yang bukan dari darah dagingnya. Dalam novel dijelaskan bahwa Kartono sangat membenci nasib yang menimpanya akibat Gulabia, istrinya tersebut yang tak lain adalah mantan selingkuhannya. Sungguh nahas nasib Kartono, pernikahannya dengan Gulabia membuat istri sah sebelumnya menggugat perceraian dan memberikan penuh hak asuh anak pertama dari pernikahan sebelumnya kepada Kartono dan Gulabia. Kebencian Kartono inilah yang menjadi sumber konflik dalam rumah tangganya dengan Gulabia. Kartono melakukan KDRT kepada istrinya dengan tujuan membunuh bayi dalam kandungan Gulabia dan sebagai pelampiasan amarahnya kepada Gulabia. Pernikahan akibat keterpaksaan di antara kedua pihak menjerumuskan pada kehidupan rumah tangga yang selalu mengarah pada kekerasan dalam rumah tangga. Oleh karena itu, konflik sosial Kartono dengan Gulabia termasuk konflik destruktif yang merusak keharmonisan rumah tangga keduanya. Adapun konflik di atas menunjukkan adanya pertentangan kepentingan Gulabia dan Kartono. Berdasarkan resolusi keberhasilan konflik, maka konflik tersebut berhasil dengan menempatkan Gulabia di posisi subordinat yang selalu mengalah pada akhirnya.

Konflik kepentingan di atas berakar dari kebencian yang merembet pada kekerasan dalam rumah tangga. Pengarang dalam novel menggambarkan rumah tangga Kartono dan Gulabia bak neraka, dimana Gulabia selalu menerima kekerasan bertubi-tubi dari Kartono. Sebagaimana dalam penelitian (Muljono, 20I5) tentang perbandingan KDRT di Jawa Barat pada tahun 2015, menunjukkan bahwa intensitas KDRT oleh suami terhadap istri di Jawa Barat cenderung lebih tinggi terjadi di Kabupaten Indramayu. Kabupaten Indramayu memiliki prosentase KDRT paling tinggi di Jawa Barat, sebagaimana pengarang menggambarkan KDRT dalam novel, yaitu dalam rumah tangga Gulabia dan Kartono. Berdasarkan hasil penelitian tersebut menunjukkan masalah sosial yang diangkat pengarang novel Aib dan Nasib adalah berdasar pada realitas sosial masyarakat Indramayu (Muljono, 2015).

Kedua, wujud konflik sosial berupa adu mulut antara tokoh Marlina dan Nurumubin terdapat dalam kutipan berikut.

\begin{abstract}
"Sampean membenci Eni cuma karena aku membenci Sumirah, Surtini, dan Dulmubin"/Jaga bicaramu itu!" /"Lalu kenapa sampean tidak pernah suka dengan Eni?” /"Hidup kita melarat, dan aku tidak mau kita tambah melarat cuma karena perempuan itu”/"Kalau sampean mengharapkan hidup kita akan sugih dengan memupuk harapan kepada Pang Randu dan Godong Gunda, sampean salah Pak"/"Mereka sekolah sedangkan kau tidak. Mereka bisa mengutak-atik mesin sedangkan kau tidak. Jelas aku menaruh harapan kepada mereka” / Sampean cuma lelaki kesepian lantaran ditinggal mati istri”" "Jaga bicaramu itu!" /"Dan sampean ingin aku kesepian agar sama seperti sampean” (Aib dan Nasib, 2019, h. 42).
\end{abstract}

Konflik sosial antara tokoh Marlina dengan Nurumubin yang tak lain merupakan ayah Marlina itu berawal dari kemarahan Marlina atas ketiadaan kabar dari Eni, kekasih Marlina, yang diantar pulang oleh Nurumubin setelah menginap semalam di rumahnya. Adu mulut terjadi lantaran kedua pihak ingin mempertahankan argumennya masing-masing. Keinginan Marlina berbenturan dengan keyakinan Nurumubin. Marlina berniat akan menikahi Eni tetapi tidak mendapat persetujuan dari pihak keluarga, yaitu Nurumubin, karena keyakinannya apabila menambah anggota keluarga berarti menambah beban, sehingga semakin memperburuk kondisi ekonomi keluarga. Nurumubin tidak menginginkan pernikahan Marlina dengan Eni akibat masalah ekonomi

Sebagaimana dalam (Jamil 2015), Simmel menjelaskan bahwa konflik dapat disebabkan oleh benturan keinginan dan kesenjangan ekonomi (Susan, 2019). Konflik dapat terjadi karena adanya 
keterikatan sistem sosial dan keberadaan lembaga sosial sebagai pihak superordinat yang memberikan batasan terhadap pihak subordinat. Benturan keinginan berakar dari keharusan Marlina untuk patuh terhadap sistem yang melibatkan keluarga dalam adat sakral pernikahan, tetapi pihak keluarganya tidak memberikan persetujuan. Marlina berkeinginan keras untuk menikahi Eni. Adapun Nurumubin ingin memperbaiki masalah ekonomi bukan menambah anggota keluarga sebagai beban ekonomi dengan pernikahan Marlina dengan Nurumubin. Marlina semakin memperpanjang konflik dengan terus memicu kemarahan Nurumubin dengan menyangkut pautkan masalah tersebut dengan keluarga besar dari pihak Nurumubin, termasuk kedua adik Marlina, Pang Randu dan Godong Gunda. Konflik Marlina dengan Nurumubin termasuk konflik destruktif, karena dalam pandangan keyakinan religius keduanya yaitu berdasarkan QS. An-Nur 32 disebutkan "Jika mereka miskin. Allah akan memampukan mereka dengan karunia-Nya. Dan Allah Maha luas (pemberian-Nya) lagi Maha Mengetahui”. Oleh karena itu, cara berpikir Nurumubin dinilai salah dalam pandangan agamanya dan merugikan Marlina. Berdasarkan resolusi keberhasilan konflik, maka konflik dalam konteks tersebut berakhir dengan sendirinya dari kedua pihak yang memilih untuk menyudahi perdebatan, serta akhirnya pernikahan tetap terjadi dan Nurumubin masih sangat membenci keberadaan Eni.

Masalah kemiskinan yang melatarbelakangi konflik sosial di atas menunjukkan realitas masalah sosial masysarakat Indramayu. Kemiskinan di Indramayu hingga saat ini masih menjadi masalah krisis yang belum juga tuntas. Berbagai penelitian telah dilakukan untuk mendapatkan solusi terbaik dalam mengatasi masalah kemiskinan, seperti penelitian tentang strategi mengatasi kemiskinan (Iryana, 2020) dan pemberdayaan masyarakat Indramayu (Di et al., 2009). Data faktual menyebutkan bahwa pada tahun 202 I kemiskinan Indramayu terus mengalami peningkatan. Dalam penulisan novel, pengarang mengangkat masalah sosial kemiskinan Indramayu dan menyajikannya bersama konflik yang sering terjadi di masyarakat akibat masalah kemiskinan.

\section{Konflik antar pribadi}

Konflik antar tokoh adalah konflik yang hanya melibatkan perseorangan. Konflik antar tokoh selalu menjadi bumbu penyedap dalam setiap alur cerita dalam karya sastra yang diciptakan pengarang (Maiti \& Bidinger, I98I). Konflik antar tokoh yang diperoleh peneliti dalam novel terdiri atas empat wujud konflik, yaitu adu mulut, pengeroyokan, sindiran, dan ketegangan. Adapun penjelasannya sebagai berikut.

\section{Adu Mulut}

Adu mulut dalam KBBI berarti percekcokan, yaitu bertengkar, bercekcok, dan berdebat. Adu mulut dapat berupa percekcokan antar tokoh akibat keteguhan tokoh mempertahankan pendapat masing-masing. Berdasarkan tabel di atas, wujud konflik sosial adu mulut dalam novel Aib dan Nasib berdasarkan perspektif George Simmel terjadi diantara beberapa tokoh. Berikut penjelasannya:

Pertama, wujud konflik sosial berupa adu mulut antara tokoh Bagong dan Boled Boleng terdapat dalam kutipan berikut.

"Njing! Kau mau ngapain?"/"Membalas perlakuanmu padaku"/"Tadi aku sudah minta maaf, Njing. Hari ini aku diminta mencuci gombal oleh bapakku. Kalau dia tau jendela kamar bobol lagi, dia bisa marah"/"Bukan urusanku"/"Kalau aku dimarahi bapakku, itu gara-gara kamu Njing!" /"Mukaku masih terasa sakit padahal sudah dua hari lebih. Kamu juga harus merasakan sakit, sama sepertiku”/"Lepaskan aku, atau aku akan berteriak!"/"Berteriaklah sesukamu"/"Lepaskan aku atau aku akan melapor ke Susanto agar dia menghajarmu!"/Saat itulah Boled Boleng melepaskan cengkraman, namun langsung mendorong Bagong Badrudin sampai tersungkur ke tanah (Aib dan Nasib, 2019, h. 190).

Konflik antara Bagong dengan Boled Boleng berupa adu mulut hingga kekerasan fisik. Konflik yang tercipta sebagai bentuk balas dendam Boled Boleng kepada Bagong yang telah mengingkari janji 
sebelumnya dan membuat Boled Boleng terluka parah hampir di sekujur tubuhnya. Konflik ini berakar dari delinkuensi remaja berupa perkelahian fisik antara Boled Boleng dan Godong Gunda yang diadu oleh Bagong. Pertengkaran mulut terjadi sebagai pembelaan Bagong untuk menghindari penyerangan yang mungkin akan dilakukan Boled Baleng secara tiba-tiba. Bagong terus memberikan pembelaan, mengumpat, dan bahkan mengancam meskipun keadaan tidak berpihak kepadanya. Kemarahan dan kebencian Boled Boleng sudah mencapai batasnya, hingga membuatnya bertindak kekerasan pada Bagong dengan mencengkram dan mendorong Bagong sampai tersungkur.

Jamil (2015) menjelaskan bahwa kebencian dan kepentingan praktis dapat menyebabkan konflik sosial (Sjoberg, 2009). Kebencian Boled Boleng terhadap Bagong yang menghianatinya menjadi akar konflik diantara keduanya. Bagong menjalankan rencana licik demi kepentingan praktisnya yaitu keinginan mengakhiri kebiasaannya yang selalu meminjami HP yang tidak lain sebatas untuk bersosial media oleh Boled Boleng, dan berakhir dengan konflik diantara keduanya. Pada dasarnya konflik akibat pengingkaran janji dan semua perbuatan keji seseorang bersifat konstruktif, akan tetapi dalam konteks tersebut konflik bersifat negatif karena menggunakan jalan kekerasan yang tentu akan semakin memperparah konflik di kemudian hari. Berdasarkan resolusi keberhasilan konflik George Simmel, maka konflik tersebut berhasil dikarenakan salah satu pihak kehilangan kekuasaan untuk menyerang. Boled Boleng memutuskan untuk mengakhiri konflik setelah mendengar ancaman yang dilontarkan Bagong Badrudin.

Perkelahian akibat delikuensi remaja menjadi masalah sosial yang masih marak terjadi. Delinkuensi remaja dominan lahir dari penggunaan teknologi seperti media sosial. Sebagaimana dalam penelitian. di salah satu sekolah Indramayu menunjukkan besarnya dampak penggunaan teknologi yaitu media sosial terhadap sikap para remaja yang cenderung berdampak negatif yaitu. Dalam novel, konflik di atas digambarkan pengarang berupa percekcokan adu mulut antar laki-laki akibat handphone yang biasa digunakan untuk bermain media sosial. Hal ini menunjukkan bahwa pengarang mengangkat permasalahan sosial realitas masyarakat Indramayu yaitu delinkuensi remaja akibat penggunaan teknologi.

Kedua, wujud konflik sosial berupa adu mulut antara tokoh Ratminah dan Rusniti terdapat dalam kutipan berikut.

"HP anakku dicolong Boled Boleng semalam”/“Jangan sembarangan menuduh anakku, begitu, Rus!. Bocor sekali mulutmu itu! Tunjukkan mana bukti kalau anakku mencuri HP anakmu!" /"Tidak perlu bukti karena anakku tahu sendiri saat Boled Boleng mencoleng”/"Kalau kau benci padaku, tidak usah bikin-bikin alasan ngaco. Salahku apa, Rus, sampai kau bikin malu aku begini?"/"HP anakku dicolong anakmu, kirik Ratminah"/"Yang kirik itu sampean Rusniti. Kalau memang kau tahu anakku mencuri HP anakmu, datanglah kemari dan bicaralah baik-baik, tidak perlulah mulutmu bocor begini” [...] (Aib dan Nasib, 2019, h. 184).

Konflik sosial antara Ratminah dan Rusniti berupa pertengkaran mulut yang disulut oleh tuduhan Rusniti pada anak Ratminah, Boled Boleng. Rusniti meneriakkan dengan lantang tuduhantuduhan tidak berdasar kepada Boled Boleng yang ditujukan kepada Ratminah dan terdengar oleh semua orang disekitarnya. Umpatan-umpatan kasar keluar dari mulut Rusniti dan dibalas pula oleh Ratminah. Faktor penyebab konflik tersebut adalah adanya ketidaksetujuan Ratminah atas tuduhan berdasarkan labelling tanpa bukti oleh Rusniti kepada anaknya, Boled Boleng.

Jamil (2015) menjelaskan bahwa manusia memiliki feeling of hostility yaitu insting saling bermusuhan (Susan, 2019). Ratminah dan Rusnity sering dijelaskan sebagai dua tokoh partner dalam bergunjing atas aib orang lain. Akan tetapi, sifat dan insting keduanya tetap akan seperti itu meskipun aib itu dilakukan oleh partnernya sendiri. Simmel juga menjelaskan bahwa hubungan dekat akan memicu adanya konflik, sebagaimana kedekatan Rusniti dan Ratminah sebagai tetangga dekat membuat keduanya mengetahui banyak hal satu sama lain termasuk aib masing-masing. Konflik sosial dalam konteks ini termasuk konflik destruktif karena akan memberikan dampak negatif bagi psikis korban 
tuduhan dan merusak hubungan dan kepercayaan antar anggota masyarakat. Berdasarkan resolusi keberhasilan konflik, maka konflik tersebut berhasil dengan adanya pihak ketiga sebagai penengah dan melerai keduanya, yaitu Baridin dan Darto, suami masing-masing.

Kasus di atas menggambarkan konflik akibat hilangnya barang elektronik yang dicuri oleh pelaku yang belum diketahui pasti. Pengarang ingin mengemas masalah sosial yang terjadi di Indramayu yaitu pencurian dalam scene novel dengan alur yang berbeda, tetapi realitas masalah sosial masyarakat tetap tersampaikan dalam novel. Sebagaimana hasil penelitian yang menunjukkan bahwa kasus pencurian di Kabupaten Indramayu tergolong sedang (Suryadi \& Supriatna, 2019). Tentu hal ini beriringan dengan kemiskinan yang masih terus meningkat. Dalam novel, pengarang mampu melihat realitas masalah sosial yang terjadi di masyarakat dan menuliskannya dalam scene cerita yang cukup unik.

Ketiga, wujud konflik sosial berupa adu mulut antara tokoh Marlina dan Kaji Basuki terdapat dalam kutipan berikut.

"Tanpa istrimu kamu adalah lelaki kere. Sampai kapanpun kamu akan tetap kere dan aku tidak suka berbisnis dengan orang kere”/"Ha?”/"Dasar perung "Heh.. Heh!" /"Dasar perung! Itulah mengapa Nurumubin selalu menganggapmu tolol, Marlina" "Dasar kaji medit... Bangsat..."/ "Keluar kamu dari sini dan jangan pernah kembali lagi”" (Aib dan Nasib, 2019, h. 184).

Konflik sosial antara Marlina dengan Kaji Basuki adalah adu mulut berisi umpatan dan penghinaan. Konflik keduanya dipicu oleh hinaan Kaji Basuki terhadap Marlina dengan menyebutnya kere, perung, dan tolol. Marlina membalasnya dengan umpatan medit dan bangsat. Kaji Basuki memuntahkan kemarahan kepada Marlina yang tak lain adalah salah satu pekerja di toko bangunannya. Sejak kesepakatan tanah Marlina dengan Kaji Basuki batal, Marlina menjadi pekerja yang buruk dan tercela dengan melakukan banyak kesalahan sebagai pekerja.

Dalam (Jamil 2015), Simmel menjelaskan bahwa lingkungan, kesenjangan ekonomi dan hubungan dalam pekerjaan termasuk penyebab adanya konflik sosial (Susan, 2019). Buruknya pekerjaan Marlina dan fakta kemiskinan Marlina menjadi bahan bakar konfliknya dengan Kaji Basuki. Konflik tersebut bersifat negatif dan konstruktif, negatif karena melalui umpatan dan pemecatan kerja yang tentu merugikan Marlina juga Kaji Basuki, tetapi konflik tersebut bersifat konstruktif karena bertujuan untuk membentuk lingkungan pekerjaan yang ideal dengan pekerja-pekerja yang ideal pula, serta kesadaran diri bagi pekerja untuk mengemban tanggungjawabnya dengan benar. Berdasarkan resolusi keberhasilan konflik, maka konflik tersebut berhasil dengan kalahnya salah satu pihak, Marlina. Hal ini ditandai dengan tindakan Marlina yang memilih menyerah dan meninggalkan pekerjaannya.

Sebagaimana kemiskinan di Indramayu masih menjadi salah satu masalah sosial utama. Hal ini tumbuh bersamaan dengan kesenjangan sosial, sehingga membentuk stratifikasi sosial secara alami. Pengarang mengangkat masalah kemiskinan masyarakat Indramayu yang mengakibatkan kesenjangan sosial antara yang kaya dan yang miskin.

\section{Pengeroyokan}

Pengeroyokan dalam KBBI berarti serangan bersama-sama. Pengeroyokan merupakan melakukan tindakan serangan secara bersama-sama atau beramai-ramai oleh dua orang atau lebih untuk menimbulkan rasa sakit pada orang lain. Berdasarkan Tabel I, wujud konflik sosial pengeroyokan dalam novel Aib dan Nasib berdasarkan perspektif George Simmel terjadi diantara tokoh Boled Boleng dengan Bagong dan Susanto, berikut penjelasannya.

Wujud konflik sosial berupa pengeroyokan antara tokoh Boled Boleng dengan Bagong Badrudin dan Susanto terdapat dalam kutipan berikut. 
Berkat bantuan Susanto, Bagong Badrudin bisa menarik Boled Boleng ke pekarangan sepi. Kedua lengan Boled Boleng dibekuk oleh Susanto sehingga ia tak dapat berkutik/"Perlihatkan pantatmu"/Boled Boleng menggelengkan kepala/"Perlihatkan!"/"Buruan!"/Saking kerasnya Susanto memelintir lengan Boled Boleng, Boled Boleng bergeming dengan agak gemetaran sehingga melakukan yang diperintahkan Susanto dan Bagong Badrudin. Dan tertangkaplah penampilan Boled Boleng setengah telanjang di kamera (Aib dan Nasib, 2019, h. 85).

Konflik sosial pengeroyokan Boled Boleng oleh Susanto dan Bagong merupakan bentuk delinkuensi remaja. Bagong dan Susanto memaksa Boled Boleng untuk menunjukkan kebodohan Boled Boleng sebagai balas dendam Bagong karena membuatnya putus dengan kekasih onlinenya di FB, Olif. Akar penyebab konflik mereka adalah ketidak terimaan yang tak lain adalah tindakan balas dendam Bagong atas kelancangan Boled Boleng mengirim gambar Boled Boleng yang lusuh kepada Olif. Olif yang mengira bahwa itu adalah Bagong membuatnya memutus hubungan dengan Bagong. Dalam novel dijelaskan bahwa Bagong sudah dua hari belum meninju Boled Boleng, sehingga membuatnya berhasrat meninjunya tentu hal ini menunjukkan bahwa Bagong memiliki feeling of hostility yang bersifat negatif karena delinkuensi remaja.

Simmel menyebutkan bahwa kisah asmara menjerumuskan seseorang ke dalam konflik sosial, seperti yang terjadi antara Bagong dengan Boled Boleng atas nafsunya terhadap Olif. Simmel mengatakan bahwa manusia memiliki feeling of hostility yang dimana secara alamiah memiliki sifat ingin saling bersaing dan bermusuhan. Seperti itulah yang terjadi pada Bagong dan Boled Boleng yang bersaing menggaet gadis-gadis di media sosial. Konflik tersebut termasuk ke dalam konflik destruktif negatif yang tentu merugikan pihak Boled Boleng. Berdasarkan pandangan resolusi keberhasilan konflik Simmel, maka konflik tersebut berhasil dengan ditandai mengalahnya Boled Boleng karena mustahil untuk melanjutkan konflik menyerang dua orang sekaligus.

Kasus korban bulliying dan pemostingan di media sosial di atas menunjukkan refleksi delinkuensi remaja masyarakat Indramayu. Media sosial menjadi faktor penyebab lahirnya delinkuensi remaja. Sebagaimana dalam penelitian. di salah satu sekolah Indramayu menunjukkan besarnya dampak penggunaan teknologi yaitu media sosial terhadap sikap para remaja yang cenderung berdampak negatif yaitu delinkuensi remaja. Dalam novel, konflik di atas digambarkan pengarang berupa pembullyan dan pengeroyokan remaja laki-laki akibat penggunaan sosial media. Hal ini menunjukkan bahwa pengarang mengangkat permasalahan sosial realitas masyarakat Indramayu yaitu delinkuensi remaja akibat penggunaan media sosial.

\section{Sindiran}

Sindiran merupakan acuan dalam mengatakan sesuatu dengan makna berbeda dari apa yang terkandung dalam rangkaian kata-katanya (Wicaksono, 20I4). Berdasarkan Tabel I, wujud konflik sosial sindiran dalam novel Aib dan Nasib berdasarkan perspektif George Simmel terjadi diantara beberapa tokoh, berikut penjelasannya. berikut.

Wujud konflik sosial berupa sindiran antara tokoh Inem dan Bagong terdapat dalam kutipan

"Menurutmu Inem, bagaimana orang seperti itu bisa hidup? Dikatakan sinting tidak bisa, dikatakan jejeg pun tidak bisa"/"Kau tidak perlu memikirkan itu, semua orang pasti bisa hidup kalau mau tetap berusaha mencari makan. Kau bisa jadi bukti. Biar utang terus, urusan mati bisa kapan-kapan. Begitu kan?” /Kampret kau ini Inem” (Aib dan Nasib, 2019, h. 23).

Konflik sosial antara Inem dengan Bagong adalah berupa sindiran. Sindiran Inem yang ditujukan pada Bagong secara tersirat terdapat dalam kalimat "Biar utang terus, urusan mati bisa kapankapan”. Kalimat tersebut bertujuan menyindir Bagong atas hutangnya yang terus bertambah tanpa sedikitpun berpikir untuk membayarnya. Sindiran Inem ditujukan kepada Bagong yang sudah 
seharusnya tidak usah memikirkan masalah orang bagaimana bisa hidup, tetapi pikirkan masalah sendiri yang terus menerus berhutang untuk melanjutkan hidup dan berusaha untuk melunasi hutangnya pada Inem. Bagong merasa tersindir keras hingga mengumpat kasar pada Inem.

Jamil (20I5) menjelaskan bahwa benturan pemahaman dan ambisi dapat menyulut suatu konflik sosial (Susan, 2019). Sindiran tercipta dari bentrokan pemahaman yang dilatarbelakangi ambisi Inem dalam mencari uang, bukan malah menyediakan uang untuk hidup orang lain. Inem berkeinginan agar Bagong melunasi hutang-hutang yang sudah terkumpul banyak di warung makannya itu. Konflik tersebut termasuk dalam konflik konstruktif karena bersifat positif untuk memberikan nasihat secara tidak langsung kepada Bagong agar tidak berhutang terus-menerus dan berusaha melunasinya. Dalam novel dijelaskan bahwa Bagong masih memiliki kedua orang tua yang dinilai mampu jika hanya untuk menyediakan makan sebagai kebutuhannya sehari-hari. Berdasarkan resolusi keberhasilan konflik, maka konflik tersebut berhasil selesai dengan mengalahnya Bagong yang pergi setelah makan dan tidak memutuskan memperpanjang konflik dengan Inem.

Kasus konflik di atas termasuk konflik ringan sindiran dan berakhir sebatas umpatan kasar. Sindiran yang cukup sensitif oleh Inem kepada Bagong, yaitu hutang piutang. Pengarang menggambarkan dalam novel budaya masyarakat yang terbiasa berhutang karena terhimpit masalah ekonomi. Budaya hutang piutang menunjukkan rendahnya daya beli masyarakat seiring rendahnya keadaan ekonomi (Wijartama \& Ibrahim, 2018). Sebagaimana budaya hutang piutang yang diangkat pengarang dalam novel, lahir seiring kemiskinan yang menimpa masyarakat Indramayu.

\section{Ketegangan}

Ketegangan dalam KBBI berarti keadaan tegang. Ketegangan dalam konflik sosial mengarah pada konflik batin tokoh, seperti rasa canggung. Ketegangan dapat terjadi pada konflik yang berkepanjangan dan belum menemukan titik temu. Berdasarkan Tabel I, wujud konflik sosial ketegangan dalam novel Aib dan Nasib berdasarkan perspektif George Simmel terjadi diantara beberapa tokoh, berikut penjelasannya.

Pertama, wujud konflik sosial berupa ketegangan antara tokoh Mang Sota dan Kaji Basuki terdapat dalam kutipan berikut.

Bukankah aku sudah berpesan kalau kau dan Uripah tidak paham cara mencoblos di TPS, kau bisa minta bantuan kepada Yuminah. Bukankah aku bilang begitu padamu sebelum kuputuskan untuk memugar rumah ini"/"Ya "Kenapa tidak kau lakukan?"/"Uripah tidak pulang dan aku mencaricari dia di hari pencoblosan itu"/"Di TPS, kau tidak memerlukan seharian untuk sekadar mencoblos namaku di kertas suara"/"Di TPS, kulihat antrian ramai sekali. Kupikir pasti perlu seharian untuk sekadar mencoblos namamu”/"Tidak begitu, Mang Sota”/"Punten Wa Kaji, Jadi aku harus bagaimana”/"Tidak mengapa Mang Sota. Toh hari pencoblosan sudah berlalu. Jadi aku cuma mau bilang kalau sebentar lagi pembangunan musala akan memakan tempat dan menghimpit sebelah kiri rumahmu"/"Ya"/"Juga, mau tidak mau, saat musim hujan nanti akan membikin rumahmu terendam banjir" (Aib dan Nasib, 2019, h. 229).

Konflik sosial berupa ketegangan tokoh Mang Sota dan Wa Kaji yang berawal dari ketidakterealisasikannya ambisi dari Wa Kaji dalam memenangkan politik elektoral dengan menjadi seorang pejabat. Wa Kaji menanyakan alasan Mang Sota tidak mencoblosnya waktu itu dengan terbersit kejengkelan mengungkit jasa pembongkaran rumah Mang Sota sebagai ajang menarik suara masyarakat. Mang Sota juga menanggapi kejengkelan Wa Kaji dengan tidak ramah akibat konflik batin Mang Sota sendiri karena kehilangan anak perempuannya, Uripah. Sebagaimana Jamil (2015) mengatakan bahwa adanya kepentingan pribadi menjadi akar konflik sosial (Susan, 2019). Wa Kaji memiliki kepentingan untuk memiliki jabatan dengan peduli kepada Mang Sota hingga membantunya membangun kembali rumah Mang Sota. Akan tetapi, ketika kepentingan itu tidak terwujud maka kepedulian itu akan musnah seketika. Konflik tersebut bersifat destruktif karena ketidak pedulian Wa Kaji jika rumah Mang 
Sota akan terendam banjir jika musim penghujan. Berdasarkan resolusi keberhasilan konflik, maka konflik di atas berakhir dengan adanya toleransi Mang Sota kepada Kaji Basuki.

Kasus di atas merefeleksikan realitas mayarakat umumnya di Indonesia yang selalu ramai akan politik uang kala mendekati pemilu. Pengarang menggambarkan upaya kandidat membeli suara rakyat dengan memberikan jasa gratis berupa pembongkaran salah satu warga miskin, Mang Sota, sebagai pencitraan. Praktik jual beli suara masih marak terjadi di Indonesia dan bukan lagi hal yang tabu. Tren money politic selalu ramai dalam setiap perhelatan pilkada, seperti jual beli suara (Umar, 2018). Sebagaimana dalam novel, pengarang mengangkat masalah money politic berupa pembongkaran dan pembangunan kembali rumah salah satu warga secara gratis sebagaimana realitas masyarakat Indonesia setiap menjelang pilkada.

Kedua, wujud konflik sosial berupa ketegangan antara tokoh Mang Sota dan Boled Boleng terdapat dalam kutipan berikut.

"Orang-orang bilang kau telah pergi jauh lantaran diusir Baridin. Orang-orang salah mengira karena kau tidak pergi kemana-mana”/Boled Boleng tampak gentar mendengar nama Baridin/"Kau tidak benar-benar jejeg, tapi juga tidak benar-benar sinting. Kau Cuma seorang pengecut" / Boled Boleng memeras keringat dingin/"Kau memperkosa Uripah? Kau tahu Uripah? Kau memperkosa Uripah? Ngomong!"/Dan barulah Boled Boleng menggelengkan kepala (Aib dan Nasib, 2019, h. 23I).

Konflik ketegangan antara Mang Sota dengan Boled Boleng berawal dari tuduhan Yuminah terhadap Boled Boleng yang menghamili Uripah, anak Mang Sota. Ketakutan dan kegelisahan Boled Boleng adalah buah dari konflik sebelumnya dengan sang ayah, Baridin, sehingga mendengar namanya saja sudah sangat membuatnya ketakutan tidak berdaya. Faktor penyebab konflik tersebut jelas ditunjukkan permasalahan sosial labelling oleh Yuminah yang menuduh Boled Boleng atas dasar ketidaknormalannya itu. Jamil (2015) menjelaskan bahwa konflik dapat tercipta karena kebencian (Sjoberg, 2009). Mang Sota telah termakan omongan Yuminah dan terlalu larut dalam kesedihannya, sehingga memulai konflik dengan Boled Boleng meskipun akhirnya terkuak kebenaran bahwa Boled Boleng benar-benar bukan pelaku yang memperkosa Uripah. Konflik tersebut termasuk dalam konflik konstruktif yang bertujuan untuk menguak kebenaran guna menjaga keutuhan sistem sosial. Berdasarkan resolusi keberhasilan konflik, maka konflik tersebut berhasil karena hilangnya kebencian Mang Sota sebagai penyebab konflik setelah terkuaknya kebenaran.

Konflik di atas berawal dari geramnya Mang Sota atas pelaku pemerkosaan pada anak perempuannya yang belum juga diketahui. Pengarang merefleksikan realitas masyarakat dalam konflik yang diangkat, yaitu kriminalitas terhadap perempuan. Masalah sosial kekerasan terhadap perempuan termasuk trafficking juga pemerkosaan perempuan masih menjadi kekhawatiran bersama. Dalam penelitian Komariah Emong Sapardjajah atas trafficking terhadap perempuan di Indramayu menunjukkan bahwa korban cenderung berasal dari keluarga miskin dan lingkungan sosial budaya masyarakat. Sebagaimana dalam novel, pengarang mengangkat kasus pemerkosaan yang terjadi pada tokoh Uripah yang tak lain merupakan anak perempuan dari warga paling miskin di Tegalurung, Indramayu.

\section{Konflik dalam Hubungan Intim}

Konflik dalam hubungan intim merupakan konflik yang terjadi antara pihak-pihak yang memiliki ikatan dan kedekatan. Konflik dalam hubungan intim yang diperoleh peneliti dalam novel terdiri atas dua wujud konflik, yaitu adu mulut dan ketegangan.

\section{Adu Mulut}

Adu mulut dalam KBBI berarti percekcokan, yaitu bertengkar, bercekcok, dan berdebat. Adu mulut dapat berupa percekcokan antar tokoh akibat keteguhan tokoh mempertahankan pendapat 
masing-masing. Berdasarkan Tabel I, wujud konflik sosial adu mulut dalam novel Aib dan Nasib berdasarkan perspektif George Simmel terjadi diantara beberapa tokoh, berikut penjelasannya.

Pertama, wujud konflik sosial berupa adu mulut antara tokoh Kicong dan Gulabia terdapat dalam kutipan berikut.

"Kalau kau menolak ciumanku, itu berarti dugaan Nurul memang benar"/"Kenapa kau sebutsebut Nurul? Dia tidak ada kaitannya dengan kita"/"Nurul memberitahuku kalau kau sedang dekat Kartono"/"Kau bodoh sekali, Kicong”/"Cium aku sekarang. Maka aku tidak akan mengaitngaitkan Nurul dengan kita”/"Kau memang bodoh, Kicong”/"Jangan kaukira aku tidak tahu kalau ciuman pertama kita itu adalah bahan taruhanmu dengan teman kampretmu itu, si Jahar"” (Aib dan Nasib, 2019, h. 65).

Konflik sosial antara Gulabia dan Kicong, sepasang kekasih, dipicu oleh penolakan Gulabia atas permintaan Kicong untuk berciuman. Adu mulut pun terjadi dan semakin diperparah dengan melibatkan peran orang ketiga diantara keduanya, yaitu Nurul dan Kartono. Kisah asmara yang dibumbui delinkuensi remaja ini memicu adanya konflik tersebut. Simmel menyebutkan konflik dapat tercipta karena adanya insting erotis. Kicong memaksa Gulabia untuk memenuhi instingnya dan memicu konflik setelah mendapat penolakan dari Gulabia. Namun konflik keduanya mereda saat Kicong terkejut mendengar pernyataan Gulabia yang mengetahui kebenaran akan rahasia taruhan Kicong dengan Jahari, temannya. Jamil (2015) menjelaskan bahwa kisah asmara menjadi salah satu penyebab konflik sosial (Susan, 2019). Masalah muncul ketika Gulabia menolak tuntutan sang kekasih. Konflik ini termasuk dalam konflik konstruktif, yaitu konflik yang menjaga keutuhan norma. Berdasarkan resolusi keberhasilan konflik, maka konflik tersebut berhasil dengan hilangnya dasar penyebab konflik setelah Kicong mengetahui alasan dan fakta dari Gulabia.

Konflik di atas menunjukkan adanya delinkuensi remaja yaitu kasus pelanggaran kesusilaan. Adanya tindakan mencium dan menempatkan perempuan sebagai korban taruhan termasuk dalam pelanggaran kesusilaan. Pengarang menggambarkan bagaimana remaja-remaja di Indramayu termasuk mereka yang masih duduk di bangku sekolah berani bertindak asusila. Sebagaimana laporan Pelayanan Kesehatan Kabupaten Indramayu pada tahun 2012 tindakan asusila remaja-remaja di bawah umur 20 tahun sangatlah tinggi hingga terjadi hamil di luar nikah, aborsi, penyakit seksual, dan lain-lain (Fitriani, 2017). Dalam novel, pengarang mengangkat realitas masalah sosial di Indramayu yaitu tindakan asusila pada remaja-remaja yang masih mengenyam bangku pendidikan dan berakhir hamil di luar ikatan pernikahan.

Kedua, wujud konflik sosial berupa adu mulut antara tokoh Marlina dan Eni terdapat dalam kutipan berikut.

(Dalam telepon) "Kenapa kau berubah begitu drastis sih, Marlina?”/"Mas! Mas! Ingat kau harus panggil aku dengan panggilan Mas! Kau dengan?!" "Sebelum kau mengancamku, kau menalakku Marlina”/“Kirim gajimu sekarang juga, jalang!”/“Kenapa kamu begitu lain, Marlina. Katakan ada apa disana"/"Dasar jalang. Kau tidak mendengarkanku?"/"Katakan saja apakah kau ingin menikahi perempuan lain?” [...] (Aib dan Nasib, 2019, h. 245).

Konflik sosial tokoh Marlina dan Eni, istrinya, berupa adu mulut dengan penuh luapan emosi dan api kecemburuan yang telah mencapai puncaknya. Kata 'jalang' berkali-kali diucapkan oleh Marlina sebagai bentuk kemarahan akibat kecemburuan terhadap Eni yang tengah kerja di Singapura. Marlina berasumsi sendiri bahwa Eni telah berselingkuh dan melakukan penyimpangan norma melalui unggahan Eni di FB nya bersama laki-laki lain dengan pipi saling menempel. Penyimpangan sosial tetap terjadi karena sudah seharusnya bagi Eni untuk tidak mengunggah kedekatan dengan lelaki lain mengingat dirinya sudah menikah dengan Marlina. 
Jamil (2015) menyebutkan bahwa konflik sosial dapat meletus akibat kecemburuan juga kesalahpahaman (Susan, 2019). Kecemburuan Marlina menciptakan kesalahpahaman diantara Marlina dan Eni, sehingga terjadilah percekcokan adu mulut penuh dengan umpatan kasar. Konflik tersebut bersifat destruktif karena konflik tersebut mengarah pada perpisahan. Berdasarkan resolusi keberhasilan konflik, maka konflik tersebut tidak berhasil menemukan titik temu dan berakhir dengan Eni mematikan telepon kepada Marlina.

Kasus konflik rumah tangga hingga perceraian yang diakibatkan oleh hubungan jarak jauh suami istri yang dimana istri bekerja sebagai TKW dan suami yang berada di rumah merupakan masalah sosial yang masih sering terjadi di Indramayu. Sebagaimana penelitian Abdul Jamil dan Fakhruddin pada tahun 2015 menunjukkan bahwa 56\% perempuan TKW adalah berstatus kawin. Hasil penelitian menunjukkan tingginya persentase istri yang mengajukan gugatan cerai akibat perselingkuhan dan poligami oleh suami (Jamil, 20I5). Pengarang menggambarkan bagaimana konflik suami istri antara Eni dan Marlina beberapa kali terjadi akibat saling tidak percaya kedua pihak, dan mengatakan bahwa kebutuhan biologis keduanya adalah masalah utama. Pengarang juga menggambarkan Marlina yang pada akhirnya memenuhi kebutuhan biologisnya bersama perempuan lain akibat kemarahannya terhadap Eni, bahkan pengarang kurang memperkuat kebenaran alasan Eni yang diungkapkan kepada Marlina mengenai foto Eni dengan laki-laki lain di media sosial. Pengarang menggambarkan betapa besar kemungkinan retakanya rumah tangga akibat hubungan jarak jauh karena istri sebagai pekerja TKW.

Ketiga, wujud konflik sosial berupa adu mulut antara tokoh Baridin dan Boled Boleng terdapat dalam kutipan berikut.

"Minggat saja kamu dari rumah ini!" /"Motormu dipinjam orang Pak, Dia bilang sebentar nanti balik lagi kemari”/"Goblok!"/"Dia bilang Cuma pinjam sebentar"/"Minggat saja kamu dari sini. Jangan sekali-kali kau tunjukkan mukamu ke sini. Hidup saja di karangan Kaji Basuki" (Aib dan Nasib, 2019, h. 29).

Konflik sosial antara Baridin dan Boled Boleng, sang anak, berupa adu mulut yang berawal dari bentrokan pemahaman. Baridin tahu benar bahwa Boled Boleng telah ditipu. Akan tetapi, kebodohan Boled Boleng tetap bersikeras bahwa motor Baridin hanya dipinjam oleh orang asing yang mengatakan bahwa akan dikembalikan setelah meminjamnya sebentar. Baridin bertindak kekerasan dan memperparah konflik dengan sang anak. Disorganisasi keluarga dengan adanya ketidakharmonisan keluarga Baridin dengan ketidaknormalan Boled menjadi faktor penyebab konflik tersebut terjadi.

Dalam (Jamil 2015), Simmel mengatakan bahwa kebodohan akan memicu konflik sosial (Susan, 2019). Kebodohan Boled Boleng terus menyulut konflik dengan berargumen akan kebenaran dirinya. Dan Baridin semakin memperparah konflik tersebut seiring kemarahan membakar dirinya hingga membuatnya bertindak kekerasan dengan memukul Boled Boleng menggunakan gagang sapu. Konflik tersebut bersifat konstruktif karena bertujuan untuk memberikan pelajaran kepada Boled Boleng agar tidak menjadi korban penipuan lagi, tetapi juga bersifat negatif karena dengan bertindak kekerasan kepada sang anak yang dapat membuatnya memendam kemarahan dalam dirinya. Berdasarkan resolusi keberhasilan konflik, maka konflik tersebut berhasil karena adanya pihak ketiga, ibu Boled, Ratminah, yang menghentikan konflik tersebut.

Kasus konflik yang berakar dari masalah sosial pencurian di atas menggambarkan realitas masalah sosial masyarakat. Sebagaimana dalam berita-berita terbaru mengabarkan maraknya pencurian sepeda motor dengan modus meminjam sebentar. Pelaku pencurian memperdayai korban dan membawa motor korban dalam waktu yang singkat. Pengarang mengangkat cerita berdasarkan realitas sosial yang terjadi di masyarakat. Masalah sosial pencurian motor dengan modus sebatas meminjam merupakan realitas dalam masyarakat yang diangkat pengarang dalam novel.

Keempat, wujud konflik sosial berupa adu mulut antara tokoh Badrudin dan Bagong, sang ayah, terdapat dalam kutipan berikut. 
"Kampret! Bocah ampek! Seharian penuh tidak tampak congor. Kemana saja kamu?”/"Di rumah aku diusir. Di luar rumah aku dicari-cari. Maumu apa sih Pak?”/"Kalau kamu keluar rumah buat kerja, aku tidak akan mencari-carimu, Bagong” [...] (Aib dan Nasib, 2019, h. I94).

Konflik sosial adu mulut antara tokoh Bagong dan Badrudin, sang ayah, berawal dari kekhawatiran bercampur marah dari seorang ayah ketika melihat Bagong babak belur. Perlakuan salah dari sang ayah menyulut balasan kemarahan Bagong kepada ayahnya. Disorganisasi keluarga dengan kenakalan anak, Bagong, menjadi faktor penyebab konflik tersebut. Simmel menjelaskan bahwa adanya lembaga sosial memiliki peran penting terhadap konflik sosial. Termasuk adanya keluarga sudah seharusnya menjadi contoh yang baik bagi sang anak, tetapi Badrudin memberikan contoh untuk bertindak kasar dan mendapat perlakuan sama dari Bagong, sehingga menjadikannya anak yang durhaka. Konflik tersebut bersifat destruktif karena menciptakan jarak semakin lebar pada hubungan ayah dan anak dan juga negatif karena terdapat tindak kekerasan. Berdasarkan resolusi keberhasilan konflik, konflik tersebut tidak menemukan titik temu dan memperparah kebencian sang anak kepada ayahnya juga kemarahan ayah kepada anaknya yang bahkan menimbulkan konflik lebih besar di kemudian hari.

Kasus konflik di atas menunjukkan adanya masalah sosial pengangguran. Konflik di atas tercipta karena keseharian Bagong sebagai pengangguran yang tidak memiliki tujuan hingga membuat sang ayah jengkel dan marah. Kabupaten Indramayu termasuk kabupaten nomor dua termiskin di Jawa Barat. Tingkat pengangguran di Indramayu sebesar II,29 \% di atas rata-rata Jawa Barat (I0,33\%) dan nasional (7,I4\%) (Syarief et al., 20I4). Pengarang mengangkat masalah sosial pengangguran yang menunjukkan realitas sosial masyarakat Indramayu.

\title{
Ketegangan
}

Ketegangan dalam KBBI berarti keadaan tegang, ketegangan dalam konflik sosial mengarah pada konflik batin tokoh, seperti rasa canggung. Ketegangan dapat terjadi pada konflik yang berkepanjangan dan belum menemukan titik temu. Berdasarkan Tabel I, wujud konflik sosial ketegangan dalam novel Aib dan Nasib berdasarkan perspektif George Simmel terjadi diantara beberapa tokoh, berikut penjelasannya.

Pertama, wujud konflik sosial berupa ketegangan antara tokoh Gulabia dan Kartono terdapat dalam kutipan berikut.

\begin{abstract}
"Dengar, Gulabia aku tidak menerima keadaan ini begitu saja tanpa imbalan. Sadar atau tidak, kau sudah membikin Yati bersedih, begitu pula orang tua dan mertuaku. Mereka bahkan membenciku sekarang. Sadar atau tidak, keputusanmu menjebakku telah menjungkirbalikkan hidupku”/"Kau benci padaku?" /"Sekarang lebih daripada benci. Tapi tidak apa-apa. Semua telah terjadi tanpa kau bicara berunding lebih dulu denganku dan membiarkanku berpikir tentang jalan lain, selain pernikahan sialan ini"/"Maaf:/"Tidak apa-apa. Sudah kubilang aku perlu imbalan atas pernikahan sialan ini. Bisa berupa uang. Bisa berupa barang. Bisa berupa lain-lain”/“Aku tidak mengerti" /"Kamu akan mengerti” (Aib dan Nasib, 2019, h. 132).
\end{abstract}

Konflik sosial antara Gulabia dan Kartono berupa ketegangan yang terjadi setelah kejadian sebelumnya yang menjebak Kartono. Gulabia telah resmi menjadi istri baru dari Kartono yang sebelumnya telah memiliki istri sah dan anak laki-laki. Konflik tersebut ditunjukkan oleh kebencian Kartono pada Gulabia atas perbuatan yang merugikan Kartono dan meminta paksa imbalan atas nasib yang telah menimpanya itu. Konflik tersebut membuahkan kesepakatan imbalan satu pihak dari Kartono atas Gulabia yang mengarah pada insting erotis yang memiliki kelainan sadisme dalam aktivitas seksnya. Hingga akhir narasi, Kartono terus menyakiti Gulabia dengan kelainannya itu. Sebagaimana Simmel dalam (Jamil 20I5) menjelaskan bahwa kepentingan praktis dapat mengakibatkan konflik sosial (Susan, 2019). Gulabia menjebak Kartono untuk memenuhi kepentingan praktisnya guna melindungi dirinya dari kemarahan dan kesedihan orang tuanya atas kebodohan yang menempatkan dirinya hamil di luar 
pernikahan. Konflik tersebut bersifat destruktif karena merusak keharmonisan rumah tangga keduanya dan juga bersifat negatif karena tidak berhenti bertindak kekerasan. Berdasarkan resolusi keberhasilan konflik, konflik tersebut berakhir dan menempatkan Gulabia sebagai pihak yang selalu mengalah karena merasa sepenuhnya kesalahan adalah karenanya.

Berdasarkan data dari Dinas Pemberdayaan Perempuan dan Perlindungan Anak Kabupaten Indramayu tahun 2019, menyebutkan bahwa kekerasan terhadap perempuan masih cenderung meningkat. Kabupaten Indramayu memiliki persentase KDRT paling tinggi di Jawa Barat (Muljono, 2015). Pengarang mengangkat realitas masalah sosial KDRT masyarakat Indramayu yang masih saja terjadi.

Kedua, wujud konflik sosial berupa ketegangan antara tokoh Eni dan Nurumubin terdapat dalam kutipan berikut.

\begin{abstract}
"Suamimu bilang kau pernah mbujang, pernah ngasuh bocah, pernah jadi buruh cuci, bahkan pernah jadi istri orang. Tapi, kenapa pekerjaanmu di rumah ini sering berantakan, Eni?”/"Aku cuma ketiduran sebentar, Pak"/“Aku cuma ketiduran sebentar Pak" cibir Nurumubin/"Baru sebentar saja sudah bikin nasi sangit, tumis asinan, dan piring pecah satu. Bagaimana kalau ketiduran lama?” (Aib dan Nasib, 2019, h. 135).
\end{abstract}

Konflik sosial antara Eni dan Nurumubin berupa ketegangan yang berawal dari ketidaksesuaian ekspektasi Nurumubin atas keberadaan Eni di rumah. Faktor penyebab konflik tersebut adalah adanya disekuilibrium gender, yaitu Nurumubin berekspektasi bahwa beban rumah tangga sepenuhnya akan diemban oleh perempuan dalam rumah tangga. Nurumubin menumpahkan kekesalannya kepada Eni atas tugas yang berantakan. Dalam novel dijelaskan bahwa Nurumubin tidak pernah senang atas pernikahan anaknya, Marlina, dengan Eni, sehingga keduanya sangat rawan terjadinya konflik sosial khususnya ketegangan. Simmel dalam (Jamil 2015) menjelaskan bahwa konflik sosial dapat terjadi karena kepentingan praktis (Susan, 2019). Nurumubin membebankan seluruh pekerjaan yang sebelumnya menjadi pekerjaannya kepada Eni, sebagaimana stigma masyarakat meyakini bahwa perempuanlah yang bertanggung jawab atas semua urusan di dalam rumah. Konflik sosial tersebut bersifat destruktif, tetapi menjaga keutuhan sistem masyarakat yang masih salah dalam pola pikir dan cara pandangnya, sehingga merugikan pihak perempuan. Berdasarkan resolusi keberhasilan konflik, konflik tersebut berhasil dengan adanya pihak ketiga, Marlina, istri Eni sekaligus putra Nurumubin yang mendinginkan Nurumubin.

Kasus konflik antara mertua dan menantu memang bukan lagi hal tabu. Dalam kehidupan bermasyarakat, tidak jarang konflik lahir akibat kedatangan orang yang bukan darah dagingnya yang memiliki kemungkinan besar menciptakan ketidakcocokan dengan anggota keluarga barunya, sehingga beberapa kali terjadi konflik. Sebagaimana menurut Fernandez (202I) bahwa mertua cenderung menolak keberadaan menantu pilihan anak laki-lakinya, sedangkan menantu cenderung menganggap mertua sebagai pengganggu dalam rumah tangga. Hal inilah yang akan memperburuk manajemen rumah tangga (Sutriani, 20I5). Perselisihan pendapat antar anggota keluarga merupakan perkara yang wajar karena konflik memang tidak dapat dipisahkan dari kehidupan, termasuk antara mertua dan menantu. Hal ini menunjukkan bahwa novel telah berhasil merefleksikan realitas masalah sosial dalam masyarakat.

Ketiga, wujud konflik sosial berupa ketegangan antara tokoh Eni dan Marlina terdapat dalam kutipan berikut.

"Kenapa kamu tidak bisa paham kalau lelaki dalam foto itu adalah anak majikanku"/"Maafkan aku Nok Eni, sekarang aku paham”/"Bagaimana aku tahu kau paham sementara kau berkoar-koar biki malu di FB. Kau pikir ocehanmu itu tidak dibaca oleh anak majikanku itu?" "Maafkan aku"/"Ya, tapi aku mau kamu tidak mencariku di FB karena aku tidak mau ribut cuma gara-gara masalah sepele" / "Ya" [...] (Aib dan Nasib, 2019, h. 235). 
Konflik sosial antara Eni dan Marlina berupa ketegangan yang ditunjukkan oleh kekesalan Eni dan penyesalan Marlina. Konflik ketegangan ini adalah kepanjangan dari hujatan Marlina di kolom komentar postingan Eni di FB sebelumnya meskipun tidak mendapat tanggapan dari Eni kecuali blokiran akun. Eni marah besar dan melarang Marlina untuk mencarinya lagi di FB. Simmel menjelaskan bahwa konflik sosial menciptakan batasan-batasan untuk kesadaran internal, sehingga menciptakan jarak (Susan, 2019). Seperti itulah Eni membatasi Marlina, sang suami, untuk tidak lagi mencarinya di FB, sehingga memperlebar jarak antara keduanya. Konflik tersebut bersifat konstruktif karena berusaha menjaga keutuhan keluarga. Berdasarkan resolusi keberhasilan konflik, konflik tersebut berhasil dengan hilangnya penyebab konflik setelah Marlina mengetahui kebenaran bahwa dirinyalah yang salah dan Eni mengalah sebab rasa cintanya kepada Marlina.

Konflik rumah tangga yang diangkat pengarang sebagaimana disebutkan berita-berita dan penelitian pada Kabupaten Indramayu, bahwa banyak kehancuran rumah tangga yang menimpa keluarga dimana suami melakukan poligami ataupun perselingkuhan ketika istri bekerja di luar negeri sebagai TKW (Jamil, 20I5). Pengarang mampu menciptakan scene cerita fiksi yang menarik dengan mengangkat realitas masalah sosial masyarakat Indramayu.

Keempat, wujud konflik sosial berupa ketegangan antara tokoh Bagong dan Badrudin terdapat dalam kutipan berikut.

"Pak" hening "Pak, mau kubikinkan kopi?"/Badrudin mengabaikannya/"Pak" hening/"Pak.

Kalau mau sesuatu, biar kuambilkan"/Badrudin beranjak pergi (Aib dan Nasib, 2019, h. 2I5).

Konflik sosial berupa ketegangan antara Bagong dan Badrudin, ayah Bagong, terjadi sebagai konflik perpanjangan dari konflik sebelumnya termasuk pembunuhan salah sasaran yang dilakukan Bagong hingga mempertemukan ibunya dengan kematian. Badrudin telah benar-benar putus asa dengan Bagong dan memilih abai terhadap anaknya itu. Simmel menjelaskan bahwa permusuhan timbal balik akan menciptakan identitas baru (Susan, 2019). Permusuhan Bagong dan Badrudin menciptakan jiwa pembunuh untuk Bagong sekaligus menciptakan keinginan Bagong untuk kabur dari rumahnya. Dalam novel dijelaskan bahwa Bagong memilih kabur dari rumahnya akibat konflik dengan sang ayah tidak kunjung selesai. Konflik tersebut termasuk ke dalam konflik destruktif karena pihak Badrudin memberikan respon negatif yang dapat memperpanjang konflik diantara keduanya. Meskipun berdasarkan resolusi keberhasilan konflik berhasil karena Bagong memilih mengalah untuk memperbaiki hubungan antara ayah dan anak.

Kasus konflik di atas menunjukkan konflik dalam keluarga, yaitu ayah dan anak. Novel menjelaskan bagaimana konflik dalam keluarga dapat membuat sang anak kabur dari rumah. Kejadian remaja kabur dari rumah memanglah masih saja terjadi hingga saat ini (Ratnawati, 2017). Sebagaimana di dalam novel, pengarang mengangkat realitas masalah sosial remaja kabur dari rumah dengan kemasan konflik yang menarik.

\section{Penyelesaiaan Konflik Sosial dalam Novel Aib dan Nasib Karya Minanto Berdasarkan Perspektif George Simmel}

Berdasarkan Tabel I, penyelesaian konflik hasil perolehan peneliti dalam novel Aib dan Nasib karya Minanto berdasarkan perspektif George Simmel terdiri atas empat penyelesaian konflik, yaitu: (I) koersi; (2) mediasi; (3) toleransi; (4) konversi, berikut penjelasannya.

\section{Koersi}

Koersi merupakan akomodasi dengan adanya unsur pemaksaan pihak yang lebih superordinat kepada subordinat baik pemaksaan fisik maupun psikis (Waluya, 2007). Berdasarkan Tabel I, penyelesaian konflik sosial koersi dalam novel $A i b$ dan Nasib berdasarkan perspektif George Simmel terjadi pada beberapa konflik antar tokoh, berikut penjelasannya. 
Pertama, penyelesaian konflik sosial berupa koersi antara tokoh Gulabia dan Kartono terdapat dalam kutipan berikut.

[...] "Katakan sekarang!" /Kau gila Kang”/"Karena kamu aku gila. Karena kamu aku merasa lebih gila daripada siapa pun"/ujar Kartono sembari mengencangkan cengkeraman. Gulabia merontaminta dilepaskan/"Katakan sekarang juga!"/Gulabia pun menurut, ia kemudian menangis (Aib dan Nasib, 2019, h. 138).

Konflik sosial Gulabia dan Kartono termasuk dalam konflik dyad yang bersifat konfrontatif. Pemaksaan Kartono sebagai seorang suami dan laki-laki kepada Gulabia yang berposisi sebagai istri dan perempuan menunjukkan penyelesaian koersi dengan pemaksaan superordinat kepada subordinat. Sebagaimana keyakinan religius keduanya bahwa posisi seorang suami berada di atas istri, sehingga suamilah yang menduduki posisi superordinat dalam rumah tangga. Gulabia memilih mengalah karena posisinya sebagai istri juga karena ketidakmampuan lagi menahan tindakan kekerasan dari suami juga laki-laki. Dalam hal ini, resolusi konflik berhasil akibat kemenangan superordinat.

Kedua, penyelesaian konflik sosial berupa koersi antara tokoh Bagong dan Boled Boleng terdapat dalam kutipan berikut.

"Lepaskan aku atau aku akan melapor ke Susanto agar dia menghajarmu!"/Saat itulah Boled Boleng melepaskan cengkraman, namun langsung mendorong Bagong Badrudin sampai tersungkur ke tanah (Aib dan Nasib, 2019, h. 190).

Berdasarkan konsep geometry of social space, konflik sosial Bagong dan Boled Boleng termasuk dalam konflik dyad yang bersifat konfrontatif. Ancaman Bagong terhadap Boled Boleng menghentikan konflik diantara keduanya. Adanya unsur subordinasi oleh Bagong kepada Boled Boleng dengan menyebut Susanto telah berhasil membuat ciut niat Boled Boleng untuk menghabisi Bagong Badrudin. Boled Boleng memutuskan untuk pergi setelah membuat Bagong tersungkur akibat mendengar ancaman Bagong karena merasa dirinya lebih lemah daripada ancaman akan Susanto. Dalam hal ini kemenangan satu pihak menjadi resolusi penyelesaian konflik.

Penyelesaian konflik koersi pada tokoh Marlina dengan Kaji Basuki menempatkan Marlina memilih mengalah dan meninggalkan pekerjaannya, karena posisinya subordinate yaitu sebagai karyawan dari bos, Kaji Basuki. Penyelesaian konflik koersi pada tokoh Bagong dengan Badrudin, Gulabia dengan Kartono, juga Boled Boleng dengan Bagong dan Susanto dapat diklasifikasikan ke dalam akomodasi koersi yang diakibatkan adanya kesenjangan status sosialnya yang menempatkan adanya pihak superordinat dan subordinat, yaitu ayah dengan anak, suami dengan istri, dan orang abnormal dengan kumpulan orang-orang normal.

\section{Mediasi}

Mediasi merupakan akomodasi yang menghadirkan pihak ketiga sebagai penengah ataupun penasihat yang bersifat netral dan tidak memiliki hak untuk membuat keputusan yang mengikat (Waluya, 2007). Mediasi sebagai bentuk negosiasi yang dimoderatori oleh pihak netral. Berdasarkan Tabel I, penyelesaian konflik sosial mediasi dalam novel Aib dan Nasib berdasarkan perspektif George Simmel terjadi pada beberapa konflik antar tokoh, berikut penjelasannya.

Pertama, penyelesaian konflik sosial berupa mediasi antara tokoh Ratminah dan Rusniti terdapat dalam kutipan berikut. 
"HP anakku dicolong anakmu, kirik Ratminah"/"Yang kirik itu sampean Rusniti. Kalau memang kau tahu anakku mencuri HP anakmu, datanglah kemari dan bicaralah baik-baik, tidak perlulah mulutmu bocor begini” [...]/Baik Darto ataupun Baridin ada di antara orang-orang, namun tak satu dari mereka angkat suara. Mereka diam-diam melerai dengan menarik lengan istri masingmasing agar tak sampai jambak-menjambak (Aib dan Nasib, 2019, h. I84).

Berdasarkan konsep geometry of social space dalam (Wolf, I978; Susan, 2019) bahwa konflik sosial Ratminah dan Rusniti termasuk dalam konflik triad yaitu melibatkan pihak ketiga diantara pihak yang berkonflik. Penyelesaian konflik mediasi ditunjukkan dengan adanya orang ketiga netral, yaitu Darto, suami Rusniti dan Baridin, suami Ratminah. Darto dan Baridin tidak memutuskan bagaimana akhir dari konflik tersebut, tetapi keduanya berusaha menarik lengan istri masing-masing untuk melerai pertengkaran tanpa berbicara atau mendiskusikan keputusan yang mengikat dan bagaimana akhir terbaik diantara keduanya, sehingga orang ketiga dalam konteks tersebut bersifat netral dan termasuk dalam akomodasi mediasi. Resolusi keberhasilan konflik diciptakan oleh adanya orang ketiga sebagai penengah yang netral.

Kedua, penyelesaian konflik sosial berupa mediasi antara tokoh Baridin dan Boled Boleng terdapat dalam kutipan berikut.

"Minggat saja kamu dari rumah ini?"/"Motormu dipinjam orang Pak, Dia bilang sebentar nanti balik lagi kemarı"/"Goblok!"/"Dia bilang Cuma pinjam sebentar"/"Minggat saja kamu dari sini. Jangan sekali-kali kau tunjukkan mukamu kesini. Hidup saja di karangan Kaji Basuki"/[...] "Malu, Pak, malu sama tetangga" isak Ratminah. Sedangkan tak satupun tetangga, yang menonton mereka, berani melerai pertikaian itu (Aib dan Nasib, 2019, h. 29).

Berdasarkan konsep geometry of social space dalam (Wolf, 1978; Susan, 2019) bahwa konflik sosial Baridin dan Boled Boleng, anaknya, termasuk dalam konflik triad yaitu adanya orang ketiga diantara pihak yang berkonflik. Penyelesaian konflik mediasi ditunjukkan dengan adanya orang ketiga bersifat netral, yaitu Ratminah, istri Baridin. Perkataan 'Malu Pak, malu sama tetangga' menunjukkan adanya peran Ratminah sebagai orang ketiga yaitu penasihat dengan sifat keputusannya tidaklah mengikat, sehingga tidak menutup kemungkinan bahwa perkataannya dapat ditolak oleh Baridin. Peran Ratminah berhasil menghentikan umpatan Baridin kepada anaknya, Boled Boleng, meskipun Baridin masih terus berusaha menghukum dengan memukuli Boled Boleng.

Ketiga, penyelesaian konflik sosial berupa mediasi antara tokoh Eni dan Nurumubin terdapat dalam kutipan berikut.

"Suamimu bilang kau pernah mbujang, pernah ngasuh bocah, pernah jadi buruh cuci, bahkan pernah jadi istri orang. Tapi, kenapa pekerjaanmu di rumah ini sering berantakan, Eni?”/“Aku cuma ketiduran sebentar, Pak"/“Aku cuma ketiduran sebentar Pak" cibir Nurumubin/"Baru sebentar saja sudah bikin nasi sangit, tumis asinan, dan piring pecah satu. Bagaimana kalau ketiduran lama?” "Sudahlah, Pak. Semua tidak akan terjadi kalau Pang Randu tidak grusa-grusu, mondar-mandir dapur tidak karuan" (Aib dan Nasib, 2019, h. 135).

Berdasarkan konsep geometry of social space dalam (Wolf, 1978; Susan, 2019) bahwa konflik sosial Eni dan Nurumubin, ayah mertuanya, termasuk dalam konflik triad yaitu adanya orang ketiga diantara keduanya, pihak yang berkonflik. Penyelesaian konflik mediasi ditunjukkan dengan adanya orang ketiga yang bersifat memihak, yaitu Marlina, suami Eni. Perkataan 'Sudahlah, Pak. Semua tidak akan terjadi kalau Pang Randu tidak grusa-grusu, mondar-mandir dapur tidak karuan’ menunjukkan keberpihakan Marlina pada istrinya, Eni. Marlina membela dengan mengoper kesalahan yang menimpa Eni kepada adiknya, Pang Randu. Dalam konteks konflik tersebut, hadirnya orang ketiga, Marlina, 
tidak berhasil menyelesaikan konflik dan sebaliknya membuat konflik semakin panjang ditambah dengan munculnya ketidak terimaan Pang Randu yang telah ditimpali kesalahan oleh kakaknya itu

\title{
Toleransi
}

Toleransi merupakan akomodasi yang terjadi tanpa adanya persetujuan resmi. Akan tetapi, tuntasnya konflik terjadi akibat rasa saling menghargai dan menghormati antar pihak yang berkonflik, bahkan secara tidak sadar konflik selesai dengan sendirinya karena keinginan untuk menghindarkan diri dari konflik (Waluya, 2007). Resolusi keberhasilan konflik toleransi menunjukkan adanya kompromi diantara pihak yang berkonflik. Berdasarkan tabel di atas, penyelesaian konflik sosial toleransi dalam novel Aib dan Nasib berdasarkan perspektif George Simmel terjadi pada beberapa konflik antar tokoh, yaitu Inem dengan Bagong, Mang Sota dengan Kaji Basuki, Mang Sota dengan Boled Boleng, dan Marlina dengan Nurumubin.

Dalam novel tidak terdapat penjelasan secara kontekstual akan penyelesaian konflik toleransi. Akan tetapi, toleransi dapat diidentifikasi melalui tindakan tokoh selanjutnya setelah terjadinya konflik yang menunjukkan tidak adanya masalah sedikitpun diantara pihak yang berkonflik. Akan tetapi, toleransi pada tokoh-tokoh tersebut berupa keinginan untuk menghindarkan diri dari konflik karena rasa saling menghormati dan secara tidak sadar konflik selesai dengan sendirinya akibat hubungan kedekatan yang teramat rekat, sehingga secara tidak sadar konflik berlalu begitu saja. Konflik-konflik yang terealisasikan oleh toleransi berakar dari jenis konflik dyad yang bersifat konfrontatif, sehingga memunculkan kesadaran internal tanpa adanya pihak ketiga yang dapat mempengaruhi akhir dari konflik.

\section{Konversi}

Konversi merupakan akomodasi yang menjadikan salah satu pihak mengalah dan dengan sendirinya mau menerima superordinat pihak lain. Konversi biasanya terjadi akibat adanya keterikatan hubungan atau emosi yang mendalam kepada pihak lain (Waluya, 2007). Kunci konversi adalah kepercayaan (Shapiro, 2016). Berdasarkan Tabel I, penyelesaian konflik sosial konversi dalam novel Aib dan Nasib berdasarkan perspektif George Simmel terjadi pada konflik antara Marlina dengan Eni.

\begin{abstract}
"Kenapa kamu tidak bisa paham kalau lelaki dalam foto itu adalah anak majikanku"/"Maafkan aku Nok Eni, sekarang aku paham"/"Bagaimana aku tahu kau paham sementara kau berkoar-koar biki malu di FB. Kau pikir ocehanmu itu tidak dibaca oleh anak majikanku itu?"/"Maafkan aku"/"Ya, tapi aku mau kamu tidak mencariku di FB karena aku tidak mau ribut cuma gara-gara masalah sepele" /"Ya" [...] (Aib dan Nasib, 2019, h. 235).
\end{abstract}

Berdasarkan konsep geometry of social space dalam (Wolf, 1978; Susan, 2019) bahwa konflik sosial Eni dan Marlina termasuk dalam konflik dyad yang bersifat konfrontatif. Akomodasi konversi secara implisit terdapat dalam dialog Eni dan Marlina dalam menanggapi konflik yang dimana memilih untuk tidak memperpanjang konflik karena keduanya adalah suami dan istri dan sebagaimana keterikatan pasangan suami istri yang memiliki kedekatan dan emosi yang mendalam. Eni menerima maaf Marlina tanpa adanya paksaan, begitu pula Marlina meminta maaf dengan tulus dan mengiyakan semua permintaan Eni. Sudah seharusnya penyelesaian konflik pribadi dalam rumah tangga yang terbaik adalah penyelesaian secara $d y a d /$ berdua, yaitu sepasang suami istri saja tanpa melibatkan orang lain yang cenderung memperparah konflik. Dalam hal ini, keberhasilan resolusi konflik adalah hilangnya dasar konflik dengan hilangnya kesalahpahaman.

Berdasarkan paparan penyelesaian konflik di atas, maka dapat disimpulkan bahwa penyebab resolusi keberhasilan konflik dengan penyelesaian konflik melalui koersi adalah akibat kemenangan satu pihak atau hilangnya kekuasaan pihak yang lain, adapun mediasi menunjukkan adanya pihak ketiga netral, toleransi menunjukkan adanya kompromi, sedangkan konversi menunjukkan hilangnya dasar konflik. 


\section{Jalan Buntu}

Konflik dapat mudah terselesaikan dengan lebih implisit jika terjadi penarikan tuntutan salah satu pihak atau bahkan pernyataan resmi. Hal ini sangat mungkin terjadi pada konflik yang tidak terdapat provokatif. Adapun konflik yang menemui jalan buntu tanpa ada penyelesaian maupun tanpa ada rasa saling mengerti maka akan memiliki implikasi yang (Baker, 1990). Sebagaimana dalam Tabel I hasil temuan peneliti, konflik yang menemui jalan buntu terjadi pada konflik Marlina dengan Eni, istrinya dan konflik antara Bagong dengan Badrudin ayahnya.

Pertama, konflik Marlina dengan Eni,

"Marlina! Mau kau apakan golok itu di Singapura"/”Tunggu saja aku ke Singapura Eni”

(Aib dan Nasib, 2019, h. 246-247).

Dialog antara Marlina dengan Nurumubin, sang ayah, menunjukkan kemarahan Marlina yang hendak membalas dendam kepada Eni. Meskipun dalam novel dijelaskan bahwa rencana Marlina ke Singapura untuk menemui Eni telah sirna, karena Marlina telah meninggal dunia. Kemarahan Marlina adalah dampak dari konflik dengan Eni di telepon sebelumnya. Berdasarkan konsep geometry of social space dalam (Susan, 2019) bahwa konflik sosial Marlina dengan Eni termasuk dalam konflik dyad konfrontatif. Akan tetapi, konflik diantara keduanya tidak menemukan titik temu akibat tidak adanya rasa saling mengerti. Hubungan suami istri diantara keduanya tidak seat saat masih berada dalam satu atap. Hubungan jarak jauh Indonesia-Singapura membuat ikatan keduanya merenggang dengan berbagai masalah yang berbeda membuat sering terjadinya konflik hingga akhirnya tidak dapat diselesaikan. Karena pada dasarnya konflik dalam hubungan intim akan mudah terselesaikan dengan hanya bertemu.

Kedua, konflik Bagong dengan Badrudin,

Sebagaimana ia dijanjikan oleh Susanto, ia akan diajak minggat jauh, jauh sekali, sampai ujung Banten. (Aib dan Nasib, 2019, h. 237).

Narasi tersebut menunjukkan rencana Bagong yang akan melarikan diri dari rumah bersama temannya Susanto. Keputusan Bagong untuk ikut Bersama Susanto adalah akibat konflik dengan Badrudin, ayahnya, yang tidak menemukan titik temu dan berakhir pada konflik saling membisu tanpa ujung. Berdasarkan konsep geometry of social space dalam (Susan, 2019) bahwa konflik sosial Bagong dengan Badrudin termasuk dalam konflik triad. Susanto menjadi orang ketiga yang semakin memperparah konflik dalam hubungan intim antara ayah dan anak itu. Susanto mempengaruhi Bagong untuk melarikan diri bersamanya dan meninggalkan sang ayah. Dampak konflik yang menemui jalan buntu memang lebih besar. Hubungan ayah dan anak menjadi rusak dan tidak dapat diperbaiki kembali karena Bagong benar-benar lari dari permasalahan, sehingga konfliknya dengan sang ayah tidak pernah selesai. Seharusnya konflik dalam hubungan intim tersebut memiliki solusi terbaik dan sangat mudah, yaitu dengan ungkapan rasa kasih sayang. Akan tetapi, kedua belah pihak tidak ada yang mau mengalah, sang ayah dan anak saling tidak mau mengerti.

\section{SIMPULAN}

Berdasarkan hasil temuan dan analisis peneliti, maka didapatkan hasil sesuai fokus penelitian, yaitu konflik sosial dalam novel Aib dan Nasib karya Minanto berdasarkan perspektif George Simmel terdiri dari: (I) tiga bentuk konflik sosial yaitu: (a) konflik kepentingan dengan satu wujud adu mulut; (b) konflik antar pribadi dengan empat wujud konflik sosial: adu mulut, sindiran, pengeroyokan, dan ketegangan; (c) konflik dalam hubungan intim dengan dua wujud konflik sosial: adu mulut dan ketegangan; (2) empat penyelesaian konflik yaitu koersi, mediasi, toleransi, dan konversi.

Analisis konflik sosial berdasarkan perspektif George Simmel mengarah pada bentuk dan penyebab konflik, serta penyelesaian konflik dengan konsep dyad dan triad. Syarat resolusi keberhasilan konflik sangat berperan dalam menentukan bagaimana penyelesaian suatu konflik. Resolusi keberhasilan 
konflik dalam novel adalah akibat kemenangan salah satu pihak atau hilangnya kekuasaan salah satu pihak, hilangnya dasar konflik, adanya pihak ketiga netral, dan kompromi. Dalam novel Aib dan Nasib konflik sosial lahir sebagai buah dari permasalahan-permasalahan sosial. Dari keseluruhan data konflik yang berjumlah I7 data, ditemukannya I0 data bersifat destruktif, dan 7 lagi bersifat konstruktif. Hasil tersebut menggambarkan bagaimana konflik yang terus berkembang di masyarakat lebih cenderung destruktif dan negatif, sehingga sudah seharusnya kondisi ini menjadi kekhawatiran bersama. Oleh karena itu, kajian ini diharapkan dapat menjadi kontemplasi masyarakat untuk menentukan langkah ke depannya sebagai proses pencegahan dan penyelesaian konflik dengan solusi yang terbaik bagi masyarakat bersama dengan melihat dari segala aspek.

\section{UCAPAN TERIMA KASIH}

Peneliti mempersembahkan artikel ini untuk pegiat literasi bahasa dan sastra serta semua pihak yang telah membantu hingga pada tahap publikasi, dan untuk Jurusan Bahasa dan Sastra Arab Fakultas Humaniora UIN Maulana Malik Ibrahim Malang.

\section{DAFTAR PUSTAKA}

Ardias, A. Y., Sumartini, S., \& Mulyono, M. (2019). Konflik sosial dalam novel Karena Aku Tak Buta karya Rendy Kuswanto. Jurnal Sastra Indonesia, 8(I), 47-56. https://doi.org/I0.15294/jsi.v8iI.29949

Baker, T. (1990). Love is never enough. Behaviour Research and Therapy, 28(6), 542-555. https://doi.org/I0.1016/0005-7967(90)90I5I-8

Beeghley, L. (1998). Book review: Problematics of sociology: The Georg Simmel Lectures, I995. $\begin{array}{llll}\text { Sociological Research Online, } & & \text { (2), } & \text { II7-II7. }\end{array}$ https://doi.org/IO.II77/I36078049800300202

Bickman, L., \& Rog, D. J. (2009). The SAGE handbook of applied social research methods. California: SAGE Publications.

Cuppen, E. (2018). The value of social conflicts, critiquing invited participation in energy projects. Energy Research and Social Science, 38(I), 28-32. https://doi.org/I0.1016/j.erss.2018.01.016

De Juan, A., Pierskalla, J., \& Schwarz, E. (2020). Natural disasters, aid distribution, and social conflict - Micro-level evidence from the 2015 earthquake in Nepal. World Development, I26, I047I5. https://doi.org/I0.1016/j.worlddev.2019.104715

Farida, N., \& Andalas, E. F. (2019). Representasi Kesenjangan Sosial-Ekonomi Masyarakat Pesisir dengan Perkotaan dalam Novel Gadis Pantai Karya Pramodya Ananta Toer. KEMBARA: Jurnal Keilmuan Bahasa, Sastra, dan Pengajarannya (e-Journal), 5(I), 74-90. https://doi.org/I0.22219/kembara.v5iI.7447

Fernandez, M. (202I). Perceptions and management strategies in a post-disaster landscape of Guatemala: Social conflict as an opportunity to understand disaster. International Joumal of Disaster Risk Reduction, 57(4), I02-I53. https://doi.org/I0.1016/j.ijdrr.202I.I02I53

Fitriani, D. (2017). Faktor lingkungan yang memengaruhi pernikahan remaja perempuan. Jurnal Kesehatan Indra Husada, 4(2), 2I-28. https:/ / doi.org/I0.36973/jkih.v4i2.8

Grossmann, K. (2019). Using conflicts to uncover injustices in energy transitions: The case of social impacts of energy efficiency policies in the housing sector in Germany. Global Transitions, I(3), I48-I56. https://doi.org/I0.I0I6/j.glt.2019.10.003

Iryana, W. (2020). Strategi mengatasi kemiskinan nelayan Eretan Wetan, Indramayu. Historia Madania: Jurnal Ilmu Sejarah, 3(2), 89-I02. https:/ / doi.org/I0.I5575/hm.v3i2.9I70

Jamil, A., \& Fakhruddin, F. (2015). Isu dan Realitas di Balik Tingginya Angka Cerai-Gugat di Indramayu. Harmoni, I4(2), I38-I59. Retrieved from https://jurnalharmoni.kemenag.go.id/index.php/harmoni/article/view/93 
Johnson, D. P. (2008). Contemporary sociological theory: An integrated multi-level approach. Springer New York.

Kaern, M., Phillips, B. S., \& Cohen, R. S. (1990). Georg Simmel and contemporary sociology. Boston: Studies in the Philosophy.

Maiti, \& Bidinger. (I98I). Evaluation of visual scoring for seedling vigour in sorghum. Journal of Chemical Information and Modeling, 53(9), 1689-1699.

Miles, M. B., Huberman, A. M., \& Saldana, J. (20I4). Qualitative data analysis. California: SAGE Publications, Inc.

Minanto. 2020. Ain dan Nasib. Tangerang: Marjin Kiri.

Muljono, P. (20I5). Analisis perbandingan kdrt oleh suami dan istri di Jawa Barat. MIMBAR, Jurnal Sosial dan Pembangunan, 3I(2), 27I-282. https://doi.org/I0.293I3/mimbar.v3Ii2.I346

Nugraha, A. A., Malang, U. M., Sosial, K., \& Sastra, S. (2019). Konflik sosial pada Novel Lelaki Harimau Karya Eka Kurniawan. 3(I), I62-I70. Retrived from http://researchreport.umm.ac.id/index.php/SENASBASA/article/view/3095

Pincott, R. (1970). The sociology of literature. European Journal of Sociology, II(I), I77-I95. https://doi.org/I0.1017/S0003975600002034

Purba, A. (20I0). Pengantar Ilmu Sastra. Sumatera Utara: USUpress.

Ratnawati, V. (2017). Kondisi keluarga dan kenakalan anak. Efektor, 4(2), I-6. https://doi.org/I0.29407/e.v4i2.962

Ravitch, S. M., \& Carl, N. M. (2019). Qualitative research: Bridging the conceptual, theoretical, and methodological. California: SAGE Publications.

Setiadi, E. M. (2020). Pengantar ringkas sosiologi: Pemahaman fakta dan gejala permasalahan sosial teori, aplikasi, dan pemecahannya. Yogyakarta: Prenada Media.

Setiawan, A., \& Musaffak, M. (2019). Eksistensi mistisisme dalam novel Amba karya Laksmi Pamuntjak. KEMBARA: Jurnal Keilmuan Bahasa, Sastra, dan Pengajarannya (e-Journal), 5(2), I46-I56. https:/ / doi.org/I0.22219/kembara.v5i2.9672

Setiawan, A., \& Musaffak, M. (2020). Praktik mistisisme Jawa dalam novel Partikel karya Dewi Lestari. KEMBARA: Jurnal Keilmuan Bahasa, Sastra, dan Pengajarannya (e-Journal), 6(2), 267 278. https://doi.org/I0.22219/kembara.v6i2.15249

Shapiro, D. (2016). Praise for Daniel Shapiro's negotiating the nonnegotiable. California: Penguin Publishing Group.

Sipayung, M. E. (2016). Konflik sosial dalam novel Maryam karya Okky Madasari: Kajian sosiologi sastra. Sintesis, IO(I), 22-34. Retrived from https://ejournal.usd.ac.id/index.php/sintesis/article/download/I64/I5I

Sjoberg, L. (2009). (Heritage of Sociology Series) Georg Simmel, Donald N. Levine (ed.)-On Individuality and Social Forms-University of Chicago Press (1972). In Gender and International Security: Feminist Perspectives.

Sugiono, S., \& Mulyono, M. (2020). Konflik antara kelompok abangan dan santri dalam novel Kantring Genjer-Genjer karya Teguh Winarsho As: Kajian soisologi sastra. Jurnal Sastra Indonesia, Y(I), 54-6I. https:// doi.org/I0.I5294/jsi.v9iI.29209

Sumarno, S. (20I4). Problema dan resolusi konflik sosial di Kecamatan Johar Baru-Jakarta Pusat. Sosio Konsepsia, $\quad 3(2), \quad$ I-I6. $\quad$ Retrived from https:// ejournal.kemsos.go.id/index.php/SosioKonsepsia/article/view/362

Suryadi, U. T., \& Supriatna, Y. (2019). Sistem clustering tindak kejahatan pencurian di wilayah Jawa Barat menggunakan algoritma K-Means. Jurnal Teknologi dan Komunikasi STMIK Subang, I2(I), I5-27. https://doi.org/I0.4756I/a.vI2iI.I47

Susan, N. (2019). Sosiologi konflik: Teori-teori dan analisis. Yoyakarta: Kencana.

Sutriani, A. (2015). Dinamika relasi menantu dengan mertua yang tinggal serumah. (Doctoral dissertation, Universitas Islam Negeri Sultan Syarif Kasim Riau). 
Syarief, A., Rustiadi, E., \& Hidayat, A. (2014). Fisheries subsector analysis in indramayu regional development. Scientifik Repository. 84-93. Retrived from http://repository.ipb.ac.id/handle/I23456789/68948

Thomas, J., \& Frisby, D. (1985). Classical sociology and cosmopolitanism: A critical defence of the social. The British Journal of Sociology, 36(3), I20-134. https://doi.org/I0.2307/590472

Umar, M. H. (2018). Hukum menjual hak suara pada pemilukada dalam perspektif fiqh Siyasi Sunni. Al-Risalah, I2(2), I-28. https:// doi.org/I0.3063I/al-risalah.vI2i02.448

Vargas-Lama, F., \& Osorio-Vera, F. J. (2020). The territorial foresight for the construction of shared visions and mechanisms to minimize social conflicts: The case of Latin America. Futures, I23(I), I02-II4. https:/ / doi.org/I0.1016/j.futures.2020.102625

Waluya, B. (2007). Sosiologi: Menyelami fenomena sosial di masyarakat. Bandung: PT Grafindo Media Pratama.

Wicaksono, A. (20I4). Catatan ringkas stilistika. Bali: Garudhawaca.

Wijartama, P. G., \& Ibrahim, R. (2018). Cara-cara penagihan utang dalam perspektif hukum perdata. Kertha Semaya: Journal Ilmu Hukum, 4(2), I-I6. Retrived from https://ocs.unud.ac.id/index.php/kerthasemaya/article/view/43547

Wolff, K. H. (1978). The sociology of Simmel. New York: The Free Press. 